Science Signaling 3 (115), ra24. [DOI: 10.1126/scisignal.2000672]

The following resources related to this article are available online at http://stke.sciencemag.org.

This information is current as of 31 March 2010.

Article Tools Visit the online version of this article to access the personalization and article tools: http://stke.sciencemag.org/cgi/content/full/sigtrans;3/115/ra24

\section{Supplemental Materials}

References

Glossary

Permissions
"Supplementary Materials"

http://stke.sciencemag.org/cgi/content/full/sigtrans;3/115/ra24/DC1

This article cites 58 articles, 20 of which can be accessed for free:

http://stke.sciencemag.org/cgi/content/full/sigtrans;3/115/ra24\#otherarticles

Look up definitions for abbreviations and terms found in this article:

http://stke.sciencemag.org/glossary/

Obtain information about reproducing this article:

http://www.sciencemag.org/about/permissions.dtl 


\title{
Differential Redox Regulation of ORAI Ion Channels: A Mechanism to Tune Cellular Calcium Signaling
}

\author{
Ivan Bogeski, ${ }^{1 \star}$ Carsten Kummerow, ${ }^{1 \dagger}$ Dalia Al-Ansary, ${ }^{1 \dagger}$ Eva C. Schwarz, ${ }^{1}$ Richard Koehler, ${ }^{1}$ \\ Daisuke Kozai, ${ }^{2}$ Nobuaki Takahashi, ${ }^{2}$ Christine Peinelt, ${ }^{1}$ Desiree Griesemer, ${ }^{1 \neq}$ \\ Monika Bozem, ${ }^{1}$ Yasuo Mori, ${ }^{2}$ Markus Hoth, ${ }^{1}$ Barbara A. Niemeyer ${ }^{1 *}$ \\ (Published 30 March 2010; Volume 3 Issue 115 ra24)
}

Reactive oxygen species (ROS) are involved in many physiological and pathophysiological cellular processes. We used lymphocytes, which are exposed to highly oxidizing environments during inflammation, to study the influence of ROS on cellular function. Calcium ion $\left(\mathrm{Ca}^{2+}\right)$ influx through $\mathrm{Ca}^{2+}$ release-activated $\mathrm{Ca}^{2+}$ (CRAC) channels composed of proteins of the ORAl family is essential for the activation, proliferation, and differentiation of T lymphocytes, but whether and how ROS affect ORAI channel function have been unclear. Here, we combined $\mathrm{Ca}^{2+}$ imaging, patch-clamp recordings and measurements of cell proliferation and cytokine secretion to determine the effects of hydrogen peroxide $\left(\mathrm{H}_{2} \mathrm{O}_{2}\right)$ on ORAI channel activity and human $T$ helper lymphocyte $\left(T_{H}\right.$ cell) function. ORAl1, but not ORAI3, channels were inhibited by oxidation by $\mathrm{H}_{2} \mathrm{O}_{2}$. The differential redox sensitivity of ORAl1 and ORAI3 channels depended mainly on an extracellularly located reactive cysteine, which is absent in ORAI3. $T_{H}$ cells became progressively less redox-sensitive after differentiation into effector cells, a shift that would allow them to proliferate, differentiate, and secrete cytokines in oxidizing environments. The decreased redox sensitivity of effector $\mathrm{T}_{\mathrm{H}}$ cells correlated with increased expression of Orai3 and increased abundance of several cytosolic antioxidants. Knockdown of ORAI3 with small-interfering RNA rendered effector $T_{H}$ cells more redox-sensitive. The differential expression of Orai isoforms between naïve and effector $T_{H}$ cells may tune cellular responses under oxidative stress.

\section{INTRODUCTION}

Intracellular $\mathrm{Ca}^{2+}$ is a second messenger involved in the regulation of a diverse range of functions (1). One of the major $\mathrm{Ca}^{2+}$ entry pathways into nonexcitable cells, such as lymphocytes and epithelial cells, is through ubiquitously expressed $\mathrm{Ca}^{2+}$ release-activated $\mathrm{Ca}^{2+}$ (CRAC) channels that are localized in the plasma membrane. $\mathrm{Ca}^{2+}$ influx through CRAC channels is activated when inositol 1,4,5-trisphosphate $\left(\mathrm{IP}_{3}\right)$ triggers $\mathrm{Ca}^{2+}$ release from intracellular stores in the lumen of the endoplasmic reticulum (ER) (2-4).The concomitant decrease in ER luminal $\mathrm{Ca}^{2+}$ triggers accumulation of the $\mathrm{ER} \mathrm{Ca}^{2+}$ sensor protein stromal interaction molecule (STIM1) into puncta close to the plasma membrane $(5,6)$. These clustered STIM1 proteins directly activate $\mathrm{Ca}^{2+}$ influx through CRAC channels, which are encoded by the Orai gene family (7-11). ORAI proteins contain four transmembrane domains with both $\mathrm{N}$ - and C-terminal intracellular domains $(12,13)$ that contain putative N-terminal calmodulinbinding domains and C-terminal coiled-coil motifs. Orai family members are highly homologous, and Orail and 3 are widely expressed at the messenger RNA (mRNA) level, with Orai2 showing a somewhat more restricted expression pattern $(14,15)$. ORAI1 proteins contain the longest

${ }^{1}$ Department of Biophysics, Saarland University, 66421 Homburg, Germany. ${ }^{2}$ Department of Synthetic Chemistry and Biological Chemistry, Kyoto University, Kyoto 615-8510, Japan.

*To whom correspondence should be addressed. E-mail: ivan.bogeski@uks.eu (I.B.); barbara.niemeyer@uks.eu (B.A.N.)

†These authors contributed equally to this work.

$\ddagger$ Present address: Department of Biology, Technische Universität Kaiserslautern, 67663 Kaiserslautern, Germany. intracellular $\mathrm{N}$ termini with two proline-rich regions and one arginine-rich region and a glycosylation site in the extracellular loop between transmembrane regions 3 and 4 (15). Neither ORAI2 nor ORAI3 contain extracellular glycosylation motifs, although ORAI3 displays the longest second extracellular loop (16). In T cells and many other cell types, CRAC channels are mainly formed by ORAI1 (7), although heteromeric channels can assemble with ORAI2 or ORAI3 $(15,17,18)$.

Reactive oxygen species (ROS) are important mediators of many physiological and pathophysiological processes $(19,20)$. They are generated in both the intracellular and the extracellular space by redox-active proteins such as members of the mitochondrial electron transfer chain and NADPH oxidase (nicotinamide adenine dinucleotide phosphate(NADPH) oxidase) $(19,21,22)$. Antioxidants clear ROS and preserve the physiological redox state of cells $(19,23)$. Of the more than 20 types of ROS, superoxide radicals $\left(\mathrm{O}_{2}{ }^{-}\right)$and hydrogen peroxide $\left(\mathrm{H}_{2} \mathrm{O}_{2}\right)$ appear to be the most biologically relevant (19). $\mathrm{H}_{2} \mathrm{O}_{2}$ is relatively stable and can diffuse across the cell membrane. It primarily acts by oxidizing cysteine residues in target proteins (19). Physiological $\mathrm{H}_{2} \mathrm{O}_{2}$ concentrations are difficult to determine and can vary from the nanomolar to the low micromolar range (24-27). The existence of so-called ROS microdomains may even yield a higher local $\mathrm{H}_{2} \mathrm{O}_{2}$ concentration $(28,29)$.

Immune cells are exposed to highly oxidizing environments during inflammation $(19,30)$. Besides having microbicidal effects during the oxidative burst of phagocytes, $\mathrm{H}_{2} \mathrm{O}_{2}$ can also act as an intracellular second messenger regulating various signaling pathways $(19,20,30)$ and may be involved in lymphocyte activation (30). It has also recently been proposed to act as a chemotactic and paracrine signal for leukocyte migration in zebrafish (26). 
However, it is not clear whether ROS affect the cellular $\mathrm{Ca}^{2+}$ signaling pathways important for lymphocyte function, in particular, if and how CRAC channels are modulated by oxidation.

\section{RESULTS}

\section{ORAl1 channels are inhibited by $\mathrm{H}_{2} \mathrm{O}_{2}$}

To test whether ORAI1 channels are molecular targets of oxidation, we analyzed the effect of ROS $\left(\mathrm{H}_{2} \mathrm{O}_{2}\right)$ on intracellular $\mathrm{Ca}^{2+}$ concentrations $\left(\left[\mathrm{Ca}^{2+}\right]_{\mathrm{i}}\right)$ and current densities (CDs) of transiently expressed ORAI1 channels in human embryonic kidney (HEK) 293 cells with stable expression of STIM1 (31), referred to as HEKS1O1 cells. As expected, depletion of internal $\mathrm{ER} \mathrm{Ca}^{2+}$ stores by thapsigargin $(\mathrm{Tg})$, an inhibitor of the sarco-endoplasmic reticulum $\mathrm{Ca}^{2+}$ adenosine triphosphatase (SERCA), induced a large sustained increase of $\left[\mathrm{Ca}^{2+}\right]_{i}$ in HEKS1O1 cells, which was about five times larger than that in HEK293 cells expressing STIM1 alone (HEKS1) (black trace in Fig. 1, A and B). Previous addition of $\mathrm{H}_{2} \mathrm{O}_{2}$ led to an initial increase in $\left[\mathrm{Ca}^{2+}\right]_{\mathrm{i}}$ at higher concentrations (see below) and to a subsequent inhibition of the Tg-induced increase in $\left[\mathrm{Ca}^{2+}\right]_{\mathrm{i}}$ with a median inhibitory concentration $\left(\mathrm{IC}_{50}\right)$ of $40 \mu \mathrm{M}$ (Fig. 1, A to C). To test the effect of $\mathrm{H}_{2} \mathrm{O}_{2}$ on ORAIl channels more directly and to exclude effects of $\mathrm{H}_{2} \mathrm{O}_{2}$ on the membrane potential or $\mathrm{Ca}^{2+}$ export, we performed patch-clamp analyses of HEKS1O1 cells and triggered ORAI1 currents by depletion of ER $\mathrm{Ca}^{2+}$ store with $\mathrm{IP}_{3}$. This induced inward currents with an average $\mathrm{CD}$ of $-33 \pm 6 \mathrm{pA} / \mathrm{pF}$ (Fig. 1, D and E) com-

pared to $-0.5 \pm 0.1 \mathrm{pA} / \mathrm{pF}$ for HEKS1 cells at $-80 \mathrm{mV}$ after $5 \mathrm{~min}$. Preincubation with $1 \mathrm{mM} \mathrm{H} \mathrm{O}_{2}$ for 10 to 20 min reduced the ORAI1 current size to $-6.8 \pm 1.9 \mathrm{pA} / \mathrm{pF}$ (Fig. 1, D and $\mathrm{E}$ ). When tested against a range of different $\mathrm{H}_{2} \mathrm{O}_{2}$ concentrations, CDs decreased with an $\mathrm{IC}_{50}$ of $34 \mu \mathrm{M}$ (Fig. 1F). Increasing $\mathrm{H}_{2} \mathrm{O}_{2}$ concentrations also caused a slowing of current activation (Fig. 1D). Addition of $\mathrm{H}_{2} \mathrm{O}_{2}$ after Tg in HEKS1O1 cells, Jurkat $\mathrm{T}$ cells, and human effector $\mathrm{T}_{\mathrm{H}}$ cells neither decreased $\left[\mathrm{Ca}^{2+}\right]_{\mathrm{i}}$ (fig. S1, A to C) nor blocked $I_{\text {CRAC }}$ (fig. S1, D to F). This suggests that oxidation may prevent activation of ORAI channels. To test whether oxidation prevents activation of ORAI channels directly or affects proteins involved in activation that would also activate homologous channels, we investigated the effects of $\mathrm{H}_{2} \mathrm{O}_{2}$ on ORAI2 and ORAI3 expressed in HEKS 1 cells. HEKS1O2 cells showed similar $\mathrm{Ca}^{2+}$ signals and inhibition by $\mathrm{H}_{2} \mathrm{O}_{2}$ (fig. S2, A and B). HEKS1O3 cells showed a smaller increase in $\left[\mathrm{Ca}^{2+}\right]_{\mathrm{i}}$ upon Tg stimulation compared to HEKS1O1, which was not decreased even by $1 \mathrm{mM} \mathrm{H}_{2} \mathrm{O}_{2}$ (Fig. 1, $\mathrm{G}$ and $\mathrm{H}$ ). Average CDs of ORAI3 were also smaller when compared to those of ORAI1 but still $\sim 10$ times larger than in HEKS1 cells $(-4.9 \pm 0.4,-33 \pm 6$, and $-0.5 \pm 0.1 \mathrm{pA} / \mathrm{pF}$, respectively; $P<0.001)$. ORAI3 currents, however, were not blocked after preincubation with $1 \mathrm{mM} \mathrm{H} \mathrm{O}_{2}$ (Fig. 1 , I and J), suggesting that the inhibitory effect of $\mathrm{H}_{2} \mathrm{O}_{2}$ is specific for ORAIl channels.

\section{A cysteine residue in ORAl1 is involved in redox sensing}

Free thiol groups of cysteine residues are the major targets of oxidation in proteins. Therefore, we compared the number and location of cysteine

B

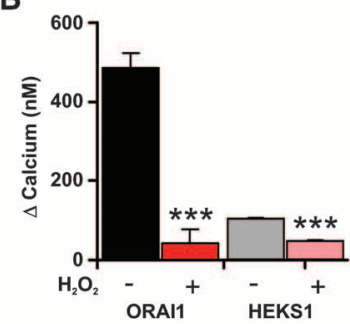

E

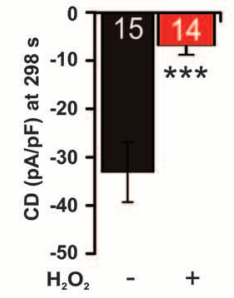

C

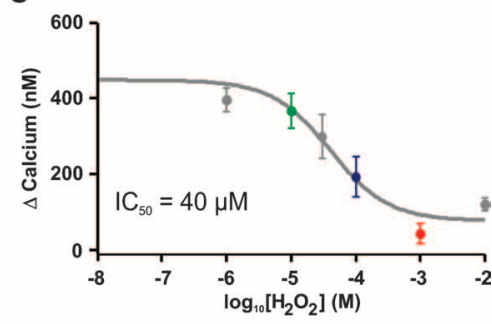

F

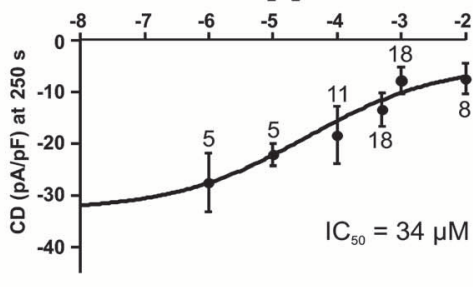
$\Delta\left[\mathrm{Ca}^{2+}\right]_{i}$ against $\left[\mathrm{H}_{2} \mathrm{O}_{2}\right]$ in HEKS1O1 cells. (D) CDs without and with $100 \mu \mathrm{M}$ or $1 \mathrm{mM}$ $\mathrm{H}_{2} \mathrm{O}_{2}$ in HEKS1O1 cells. (E) Average $\mathrm{CD}$ in the absence (black) or with $1 \mathrm{mM} \mathrm{H}_{2} \mathrm{O}_{2}$ (red). (F) Plot of CD against $\left[\mathrm{H}_{2} \mathrm{O}_{2}\right]$ in HEKS1O1 cells. (G) $\left[\mathrm{Ca}^{2+}\right]_{i}$ in HEKS1O3 cells untreated (black, $n=53$ ) or treated with $1 \mathrm{mM} \mathrm{H}_{2} \mathrm{O}_{2}$ (red, $n=54)$. (H) $\Delta\left[\mathrm{Ca}^{2+}\right]_{\mathrm{i}}$ be-

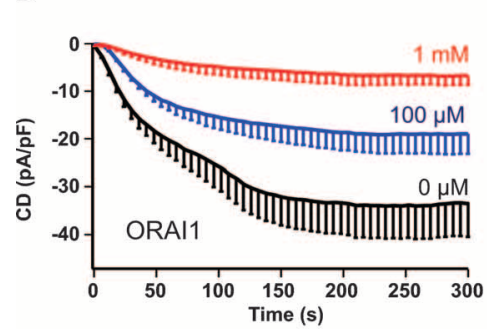

G

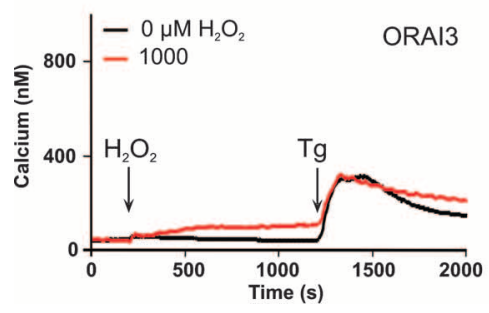

H

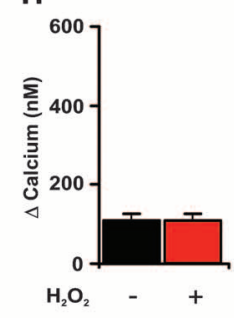

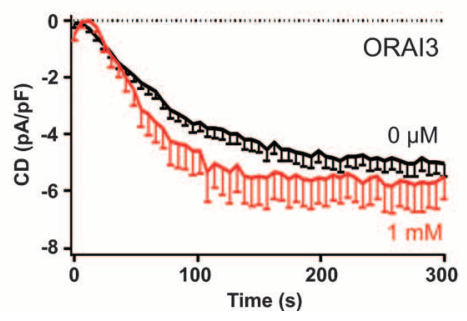

$\mathbf{J}$

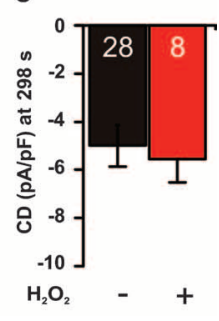

tween 1200 and $2000 \mathrm{~s}$ after treatment with $1 \mathrm{mM} \mathrm{H}_{2} \mathrm{O}_{2}$ (red) or without $\mathrm{H}_{2} \mathrm{O}_{2}$ (black) in $\mathrm{HEKS} 1 \mathrm{O} 3$ cells. (I) CD of $\mathrm{HEKS} 1 \mathrm{O} 3$ cells plotted versus time; black (untreated), red $\left(1 \mathrm{mM} \mathrm{H}_{2} \mathrm{O}_{2}\right)$. (J) Average $\mathrm{CD}$ with (red) or without $\mathrm{H}_{2} \mathrm{O}_{2}$ (black). ${ }^{* \star *} P<0.001$ (unpaired Student's $t$ test). Error bars indicate means \pm SEM. 
residues within the ORAI1 and ORAI3 proteins. ORAI1 contains three cysteines at amino acid positions 126, 143, and 195 (Fig. 2A). ORAI3 also contains cysteine residues at the first two homologous positions, but lacks the homolog of $\mathrm{Cys}^{195}$. ORA13 also contains two additional closely spaced cysteines within the extracellular loop between transmembrane regions S3 and S4 (Fig. 2D) that are likely to form a disulfide bond. To detect reactive cysteines in ORAI1 and ORAI3, we incubated permeabilized HEK cells transfected with the relevant green fluorescent protein (GFP)-tagged ORAI protein with DTNB-2Biotin (DTNB-2Bio), which reacts with free thiol groups and can be purified by avidin-based affinity purification. Free thiol groups that can be blocked by pretreatment with $\mathrm{H}_{2} \mathrm{O}_{2}$ were detected in ORAI1, whereas no overt retention was detected for ORAI3 (Fig. 2J). Although ORAI3 protein input is lower, this finding suggests that Cys ${ }^{195}$ may be a possible redox sensor of ORAI1 (Fig. 2J). Mutation of $\mathrm{Cys}^{195}$ to serine (C195S; see Fig. 2A) significantly reduced the block of Tg-induced increase in $\left[\mathrm{Ca}^{2+}\right]_{\mathrm{i}}$ by $1 \mathrm{mM} \mathrm{H}_{2} \mathrm{O}_{2}$ relative to that of wild-type ORAI1 (Fig. 2, B and K). Consistently, the $\mathrm{H}_{2} \mathrm{O}_{2}$-induced current inhibition was significantly smaller for C195S than for the wild type (Fig. 2, C and L). Although some current inhibition remained, Cys $^{195}$ appears to be a major reactive cysteine conferring oxidationinduced reduction of channel activity. To further test the significance of $\mathrm{Cys}^{195}$, we created a potential gain-of-function mutation in Orai3 by exchanging the homolog of Cys ${ }^{195}$, namely, Gly ${ }^{170}$, with cysteine (G170C; Fig. 2D and fig. S2C). As seen from both $\mathrm{Ca}^{2+}$ imaging data (Fig. 2, E and K) and patch-clamp analyses (Fig. 2, F and L), introducing the G170C mutation bestowed redox sensitivity on ORAI3, suggesting that $\mathrm{Cys}^{195}$ is an important redox sensor in ORAI1. Because some current inhibition remained in the ORAI1 C195S mutant, we also mutated the remaining two cysteine residues of ORAI1 (Fig. 2G). The ORAI1 triple mutant (TM, C195S-C143S-C126S) had reduced $\mathrm{Ca}^{2+}$ signals relative to those of the wild type, which were not inhibited by $\mathrm{H}_{2} \mathrm{O}_{2}$ (Fig. 2, $\mathrm{H}$ and $\mathrm{K})$. The triple mutant currents were slightly reduced relative to those of the wild type $(-20 \pm 3.9 \mathrm{pA} / \mathrm{pF}, P=0.08)$ but again showed a complete loss of redox sensitivity (Fig. 2, I and L). In parallel to the electrophysiological analyses of the mutants, we also investigated their reactive cysteine content by incorporation of DTNB-2Bio. ORAI1C195S incorporated less DTNB-
Fig. 2. Identification of Cys ${ }^{195}$ as the major redox sensor of ORAI1. (A) Schematic topology of ORAl1, cysteine (red), and cysteine-to-serine mutation (blue). (B) $\left[\mathrm{Ca}^{2+}\right]$ in $\mathrm{HEKS} 1$ cells expressing ORAl1C195S mutant (black and red) or ORAI1 wild type (WT; gray and pink) channels, without $\mathrm{H}_{2} \mathrm{O}_{2}$ [black $(n=45)$ and gray] or with $1 \mathrm{mM} \mathrm{H}_{2} \mathrm{O}_{2}$ [red ( $n=58$ ) and pink]. (C) CD of HEKS1O1C195S plotted versus time; the color code corresponds to that in $(B)$. ( $D$ to F) Same as in (A) to (C) for ORAI3G170C mutant ( $n=$ 48 for black and 53 for red); gray and pink are from ORAI3 WT. (G to I) Same as in (A) to (C) for ORAI1TM mutant $(n=$ 31 for black and 54 for red). (J) Immunoblot probed with an antibody against GFP of avidin-bound fractions (top panel) and total cell lysates (bottom panel) from HEK cells transfected with EGFP-ORAl1, EGFP-ORAI1C195S, EGFPORAI1TM, or EGFP-ORAI3 and incubated with DTNB2Bio. (K) Averaged $\Delta\left[\mathrm{Ca}^{2+}\right]_{\mathrm{i}}$ in HEKS1 cells transfected with ORAI1C195S, ORAI1WT (pink, $1 \mathrm{mM}$ ), ORAI1TM, and ORAI3G170C, untreated (black) or treated (red, $1 \mathrm{mM}$ ) with $\mathrm{H}_{2} \mathrm{O}_{2}$. (L) Averaged CD of ORAl1C195S, ORAI1WT (pink, $1 \mathrm{mM}$ ), ORAl1TM, and ORAI3G170C, untreated (black) or treated (red, 1 mM) with $\mathrm{H}_{2} \mathrm{O}_{2}$. ${ }^{\star} P<0.05,{ }^{\star \star} P<0.01,{ }^{\star \star}{ }^{\star *} P<0.001$, unpaired Student's $t$ test.
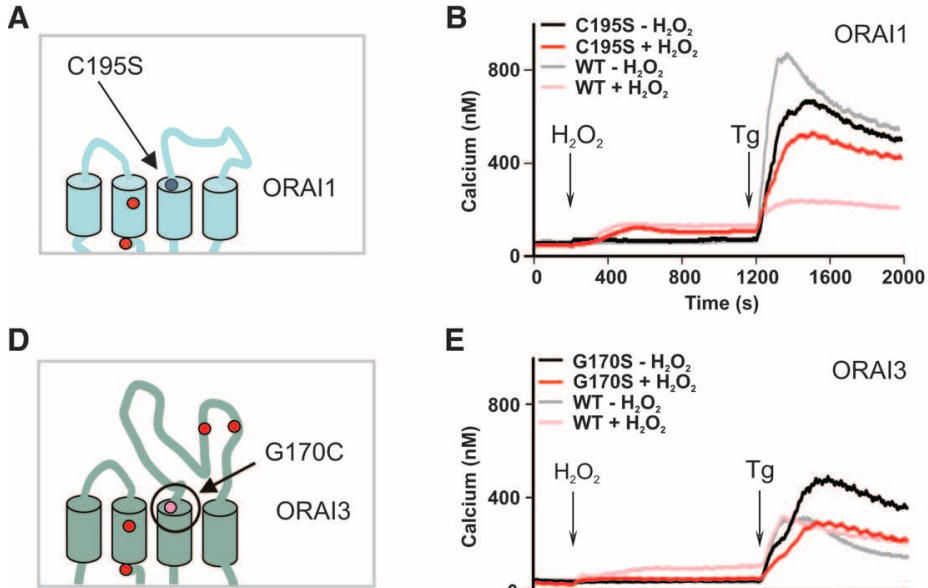

G

E

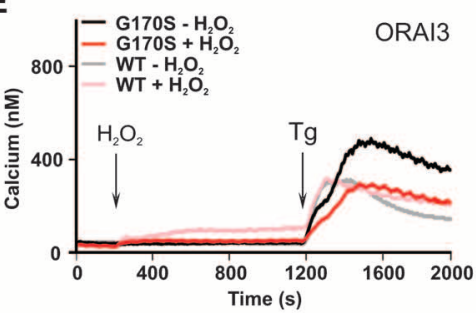

H

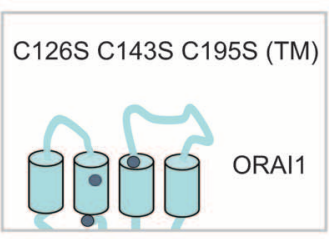

$\mathbf{J}$
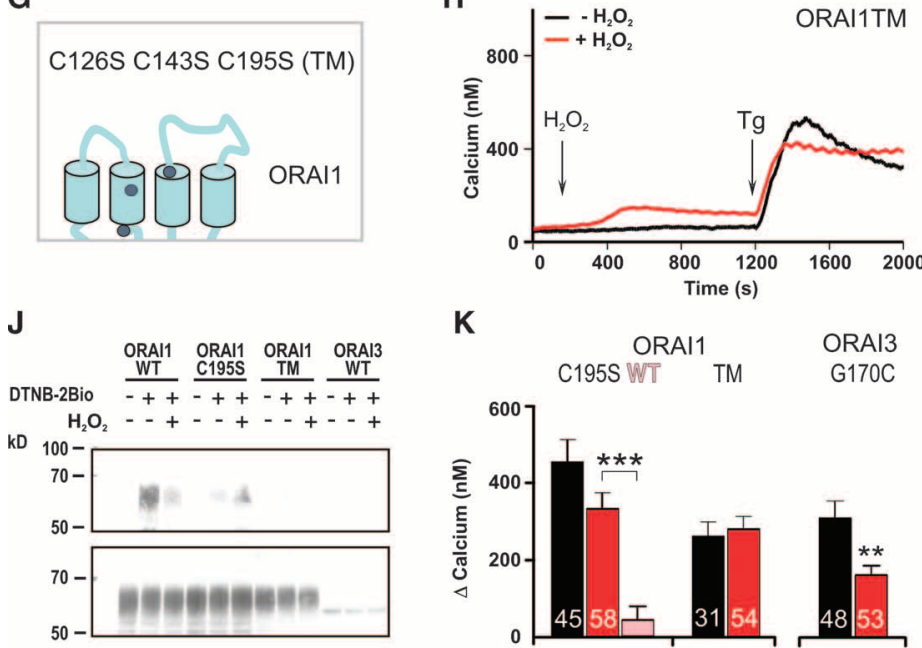

K

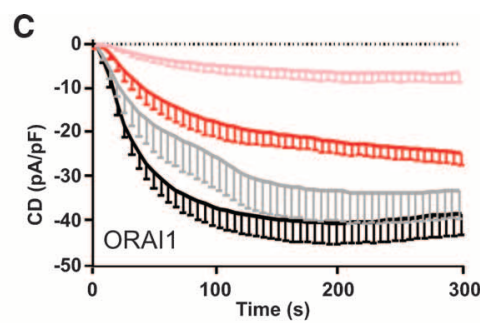

$\mathbf{F}$

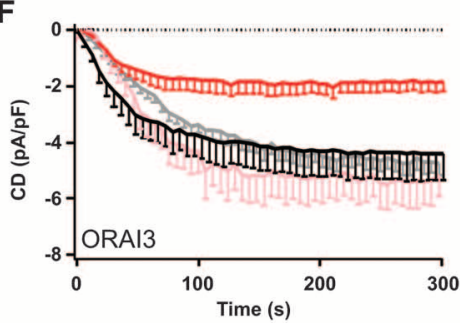

I

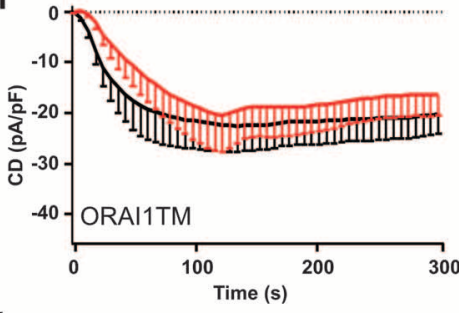

$\mathbf{L}$

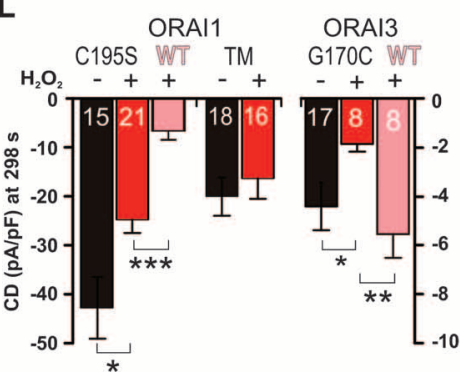


2Bio than ORAI1 wild type, whereas no incorporation was detected in the triple mutant of ORAI1 or ORAI3 (Fig. 2J). That the triple cysteine ORAI1 mutant still formed functional channels unaffected by high concentrations of $\mathrm{H}_{2} \mathrm{O}_{2}$ argues against a major role for cysteines in subunit assembly and against redox regulation of components involved in ORAI1 activation (i.e., STIM1) as the cause for reduced currents. None of the mutants showed a gross alteration of the current-voltage relationship, indicating no major alteration of the selectivity filter (fig. S2, D and G).

\section{Redox regulation of $\mathrm{Ca}^{2+}$ homeostasis in human $T$ helper cells depends on their differentiation status}

Upon migration to sites of inflammation, effector $T$ helper $\left(T_{H}\right)$ cells need to function with an optimal and appropriate response despite highly oxidizing environments. To investigate the physiological importance of redox regulation of ORAI channels, we investigated the effects of $\mathrm{H}_{2} \mathrm{O}_{2}$ on $\left[\mathrm{Ca}^{2+}\right]_{\mathrm{i}}$ both in naïve $\mathrm{CD}^{+} \mathrm{T}_{\mathrm{H}}$ cells that have never been exposed to antigen and in differentiated effector human $\mathrm{CD}^{+} \mathrm{T}_{\mathrm{H}}$ cells. To induce effector status, naïve $\mathrm{T}_{\mathrm{H}}$ cells isolated from human blood were stimulated with beads coated with antibodies against CD3 and CD28 (32). Similar to the HEKS1O1 cells, $\mathrm{T}_{\mathrm{H}}$ cells responded to an acute application of $\mathrm{H}_{2} \mathrm{O}_{2}$ with an increase in $\left[\mathrm{Ca}^{2+}\right]_{\mathrm{i}}$ in a concentration-dependent manner (fig. S3, $A$ and $B$ ). Naïve $T_{H}$ cells responded with an apparent median effective concentration $\left(\mathrm{EC}_{50}\right)$ of $\sim 130 \mu \mathrm{M}$ and were more sensitive than effector $\mathrm{T}_{\mathrm{H}}$ cells that responded with an apparent $\mathrm{EC}_{50}$ of $\sim 740 \mu \mathrm{M}$ (fig. S3C). This initial $\mathrm{Ca}^{2+}$ increase was not due to CRAC channel activation because it was not inhibited by $100 \mu \mathrm{M}$ of the CRAC channel inhibitor, 2-aminoethoxydiphenyl borate (2-APB) (fig. S3D). The rate of the initial $\mathrm{Ca}^{2+}$ increase was inhibited by flufenamic acid (FFA), which interferes with nonselective cation channels (fig. S3D) (33). Patch-clamp analyses of Jurkat $\mathrm{T}$ cells revealed an $\mathrm{H}_{2} \mathrm{O}_{2}(1 \mathrm{mM})$-induced activation of a nonselective, outwardly rectifying conductance, which was blocked by FFA (fig. S3, E to G). These findings are in agreement with reports that transient receptor potential cation channel subfamily M (TRPM) channels are expressed in human $\mathrm{T}$ cells $(34,35)$ and are activated by $\mathrm{H}_{2} \mathrm{O}_{2}(36,37)$. In summary, the $\mathrm{H}_{2} \mathrm{O}_{2}$ induced $\mathrm{Ca}^{2+}$ influx is not mediated by CRAC channels but by nonselective cation channels.

The $\mathrm{H}_{2} \mathrm{O}_{2}$ sensitivity of ORAI1 channels predicts that store-operated $\mathrm{Ca}^{2+}$ signals in $\mathrm{T}_{\mathrm{H}}$ cells should be inhibited by $\mathrm{H}_{2} \mathrm{O}_{2}$. We tested this prediction and found that the Tg-induced increase in $\left[\mathrm{Ca}^{2+}\right]_{\mathrm{i}}$ in naïve and effector $\mathrm{T}_{\mathrm{H}}$ cells is dose-dependently inhibited by preincubation with $\mathrm{H}_{2} \mathrm{O}_{2}$. To analyze this effect independently of the initial $\left[\mathrm{Ca}^{2+}\right]_{\mathrm{i}}$ rise induced by $\mathrm{H}_{2} \mathrm{O}_{2}$ (fig. S3), we compared the $\mathrm{Tg}$-induced increase in $\left[\mathrm{Ca}^{2+}\right]_{\mathrm{i}}$ in "iso-cells," that is, in cells with comparable $\left[\mathrm{Ca}^{2+}\right]_{\mathrm{i}}(30$ to $80 \mathrm{nM})$ in the presence of $10 \mu \mathrm{M} \mathrm{H} \mathrm{H}_{2} \mathrm{O}_{2}$ before addition of $\mathrm{Tg}$. Following Tg activation, a significant reduction in $\left[\mathrm{Ca}^{2+}\right]_{\mathrm{i}}$ was observed in naïve $\mathrm{T}_{\mathrm{H}}$ cells, whereas effector $\mathrm{T}_{\mathrm{H}}$ cells were much less sensitive (Fig. 3, A and C). We then analyzed $\Delta\left[\mathrm{Ca}^{2+}\right]_{i}$ in the absence and presence of different $\mathrm{H}_{2} \mathrm{O}_{2}$ concen- trations and obtained $\mathrm{IC}_{50}$ values of $7 \mu \mathrm{M}$ for naïve $\mathrm{T}_{\mathrm{H}}$ cells versus $51 \mu \mathrm{M}$ for effector $\mathrm{T}_{\mathrm{H}}$ cells (Fig. 3D). To investigate the differential $\mathrm{H}_{2} \mathrm{O}_{2}$ effect independently of changes in membrane potential, we performed voltage-clamp experiments. Recordings of $I_{\text {CRAC }}$ in naïve $\mathrm{T}_{\mathrm{H}}$ cells revealed extremely small currents barely distinguishable from leak currents. We therefore used Jurkat $\mathrm{T}$ cells, in which $\mathrm{Ca}^{2+}$ imaging responses toward $\mathrm{H}_{2} \mathrm{O}_{2}$ are similar to naïve $\mathrm{T}_{\mathrm{H}}$ cells (fig. $\mathrm{S} 3 \mathrm{H}$ ). $I_{\text {CRAC }}$ was inhibited by $87 \%$ in the presence of $500 \mu \mathrm{M} \mathrm{H}_{2} \mathrm{O}_{2}$ (Fig. 3, E and F). $I_{\text {CRAC }}$ of effector $\mathrm{T}_{\mathrm{H}}$ cells, however, showed a reduced sensitivity toward $\mathrm{H}_{2} \mathrm{O}_{2}$ with only $\sim 40 \%$ inhibition (Fig. $3 \mathrm{~F}$ ). Thus, CRAC channels in $\mathrm{T}_{\mathrm{H}}$ effector cells are less susceptible toward $\mathrm{H}_{2} \mathrm{O}_{2}$ than those in naïve $\mathrm{T}_{\mathrm{H}}$ cells.

\section{Viability and interleukin-2 (IL-2) secretion are regulated by ROS in a $T_{H}$ cell differentiation-dependent manner} Changes in intracellular $\mathrm{Ca}^{2+}$ signaling regulate activation, differentiation, and proliferation of T cells. Thus, we investigated the effects of $\mathrm{H}_{2} \mathrm{O}_{2}$ on naïve and effector $\mathrm{T}_{\mathrm{H}}$ cell viability and cytokine production. $\mathrm{H}_{2} \mathrm{O}_{2}$ $(100 \mu \mathrm{M})$ was added to the medium of $\mathrm{T}_{\mathrm{H}}$ cells at different time points after contact with beads coated with antibodies against CD3 and CD28 triggered induction of effector status, and viability was measured 24 hours later (see Materials and Methods for details). Although $100 \mu \mathrm{M}$ $\mathrm{H}_{2} \mathrm{O}_{2}$ completely eliminated naïve $\mathrm{T}_{\mathrm{H}}$ cells (Fig. 4A), effector $\mathrm{T}_{\mathrm{H}}$ cells became progressively less sensitive with increasing time of differentiation before addition of $\mathrm{H}_{2} \mathrm{O}_{2}$ (Fig. 4B). When viability was measured against a range of $\mathrm{H}_{2} \mathrm{O}_{2}$ concentrations, naïve $\mathrm{T}_{\mathrm{H}}$ cells had an $\mathrm{IC}_{50}$ value significantly lower than that of effector $\mathrm{T}_{\mathrm{H}}$ cells, $\sim 40$ and $\sim 200 \mu \mathrm{M} \mathrm{H}_{2} \mathrm{O}_{2}$, respectively (Fig. 4, C and D). A low concentration of $\mathrm{H}_{2} \mathrm{O}_{2}(1 \mu \mathrm{M})$ slightly increased the viability of effector $\mathrm{T}_{\mathrm{H}}$ cells (Fig. $4 \mathrm{D} ; P=0.054$ ). Furthermore, we measured the amount of interleukin-2 (IL-2) secreted into the external medium by $\mathrm{T}_{\mathrm{H}}$ cells treated with $100 \mu \mathrm{M} \mathrm{H}_{2} \mathrm{O}_{2} 24$ hours before
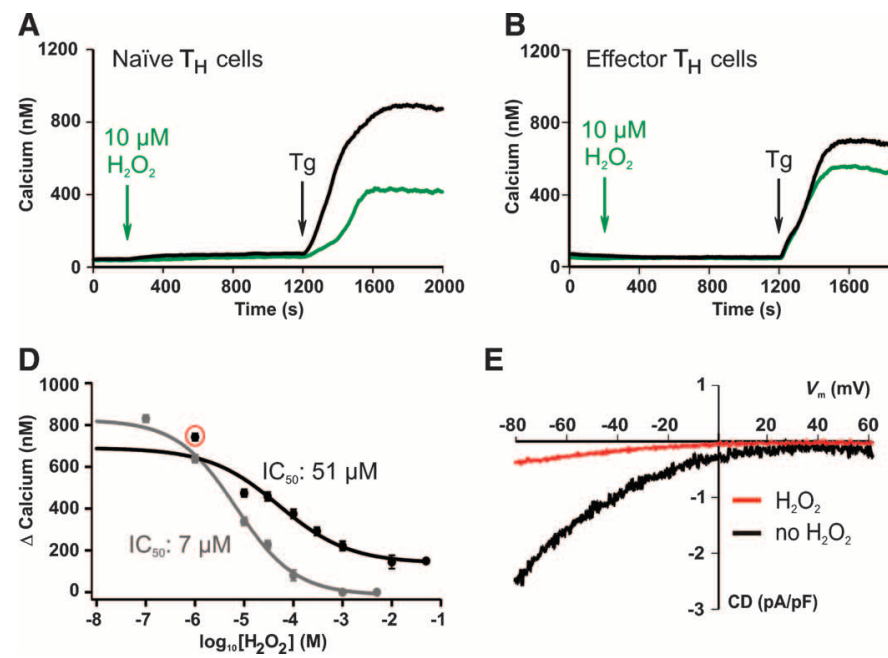

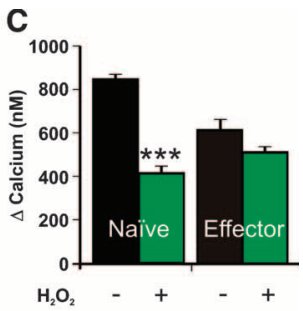

Fig. 3. Naïve and effector $T_{H}$ cells show differential redox sensitivities. (A and $\mathrm{C}$ ) $\left[\mathrm{Ca}^{2+}\right]_{i}$ and $\Delta\left[\mathrm{Ca}^{2+}\right]_{i}$ in naïve $T_{H}$ iso-cells and ( $B$ and $C$ ) in effector $T_{H}$ iso-cells. Cells defined as iso-cells were selected for resting $\left[\mathrm{Ca}^{2+}\right]_{\mathrm{i}}$ between 30 and $80 \mathrm{nM}$. Green, $10 \mu \mathrm{M} \mathrm{H}_{2} \mathrm{O}_{2}, n=114$ for naïve and 189 for effector; black, no $\mathrm{H}_{2} \mathrm{O}_{2}, n=442$ for naïve and 154 for effector. (D) Dependence of $\Delta\left[\mathrm{Ca}^{2+}\right]_{\mathrm{i}}$ on $\left[\mathrm{H}_{2} \mathrm{O}_{2}\right]$ for the Tg-triggered effect in naïve (gray) and effector $\mathrm{T}_{\mathrm{H}}$ cells (black). The red circle denotes an increased $\Delta\left[\mathrm{Ca}^{2+}\right]_{\mathrm{i}}$ of effector $\mathrm{T}_{\mathrm{H}}$ cells with $1 \mu \mathrm{M} \mathrm{H}_{2} \mathrm{O}_{2}$ compared to control. (E) I CRAc current-voltage relationships from Jurkat T cells. Black trace, untreated; red trace, $500 \mu \mathrm{M} \mathrm{H}_{2} \mathrm{O}_{2}$. (F) Quantification of average ICRAC CDs in Jurkat $T$ cells and effector $T_{H}$ cells. Black, untreated; red, $500 \mu \mathrm{M} \mathrm{H}_{2} \mathrm{O}_{2}$. Numbers within the bars indicate the number of cells. ${ }^{\star} P<0.05$, ${ }^{\star *}{ }^{*} P<0.001$, unpaired Student's $t$ test. 
or in control cells. Naïve $\mathrm{T}_{\mathrm{H}}$ cells secreted negligible levels of IL-2 (Table 1). In contrast, effector $T_{H}$ cells secreted measurable amounts of IL-2, which were reduced by pretreatment with $100 \mu \mathrm{M} \mathrm{H}_{2} \mathrm{O}_{2}$. This inhibition progressively decreases with differentiation (Table 1 ).

Differential Orai3 expression modulates redox sensitivity Given the differential redox regulation of ORAI1 and ORAI3, we tested if the reduced redox sensitivity of effector $T_{H}$ cells could be explained by a relative up-regulation of Orai3 expression. We performed quantitative reverse transcription polymerase chain reaction (qRT-PCR) from naïve
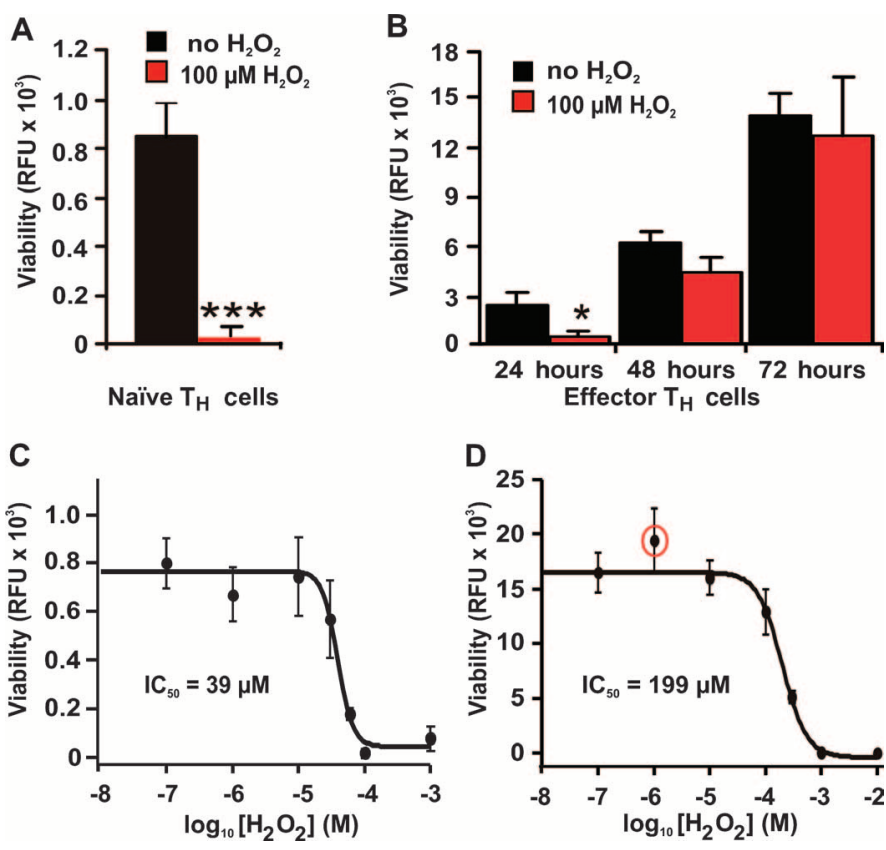

Fig. 4. $\mathrm{H}_{2} \mathrm{O}_{2}$ differentially affects the viability of $\mathrm{T}_{\mathrm{H}}$ cells. (A) Viability of naîve $\mathrm{T}_{\mathrm{H}}$ cells without (black) and with (red) $100 \mu \mathrm{M} \mathrm{H}_{2} \mathrm{O}_{2}$ measured in relative fluorescence units (RFU). (B) Viability of effector $T_{H}$ cells at different time points of differentiation without (black) and with (red) $100 \mu \mathrm{M}$ $\mathrm{H}_{2} \mathrm{O}_{2}$. (C) $\mathrm{H}_{2} \mathrm{O}_{2}$ dose dependence of naïve $\mathrm{T}_{\mathrm{H}}$ cell viability. (D) $\mathrm{H}_{2} \mathrm{O}_{2}$ dose dependence of effector $\mathrm{T}_{\mathrm{H}}$ cells treated with $\mathrm{H}_{2} \mathrm{O}_{2} 72$ hours after bead stimulation. The red circle denotes an increased viability of effector $\mathrm{T}_{\mathrm{H}}$ cells with $1 \mu \mathrm{M} \mathrm{H}_{2} \mathrm{O}_{2}$ compared to control. Viability was determined 24 hours after the addition of $\mathrm{H}_{2} \mathrm{O}_{2}$. ${ }^{*} P<0.05$, ${ }^{* \star *} P<0.001$, unpaired Student's $t$ test. and effector $\mathrm{T}_{\mathrm{H}}$ cells and found that Orai3 showed higher mRNA expression in effector than in naïve $\mathrm{T}_{\mathrm{H}}$ cells, whereas expression of Orail was not significantly changed (Fig. 5A). The relative ratio of Orail/Orai3 expression was thus significantly decreased after 3 days of differentiation (Fig. 5B). We then transfected HEKS1 cells with an Orai1/Orai3 ratio of 5:1 to mimic the appearance of low amounts of Orai3 in native systems and measured the percentage of current inhibition by $\mathrm{H}_{2} \mathrm{O}_{2}$. Coexpression of Orai3 significantly reduced current inhibition, indicating that changing the Orail/Orai3 mRNA ratio can alter $\mathrm{H}_{2} \mathrm{O}_{2}$ sensitivity (Fig. 5C). These data suggest that the presence of ORAI3 subunits either by themselves or in a heteromeric complex with ORAI1 alters $\mathrm{H}_{2} \mathrm{O}_{2}$ sensitivity.

If up-regulation of Orai 3 causes effector $\mathrm{T}_{\mathrm{H}}$ cells to become less sensitive toward extracellular ROS, down-regulation of Orai3 expression should render them more sensitive. To test this hypothesis, we transfected $\mathrm{T}_{\mathrm{H}}$ cells 24 hours after bead stimulation either with a pool of two siRNAs against Orai3 (O3 siRNA) or with a control siRNA (CTRL siRNA). Orai3 mRNA levels were down-regulated by O3 siRNA, whereas Orail mRNA levels were unaffected, as analyzed by qRT-PCR (Fig. 5D). The relative ratio of Orail/Orai3 expression was significantly increased in the O3 siRNA-treated cells when compared to the CTRL siRNA-treated cells (Fig. 5E). We confirmed the down-regulation of the ORAI3 protein with O3 siRNA by analyzing protein levels of overexpressed ORAI3-GFP in HEKS1 cells (fig. S4). We next measured the sensitivity of Tg-induced $\mathrm{Ca}^{2+}$ increase toward $100 \mu \mathrm{M} \mathrm{H}_{2} \mathrm{O}_{2}$. Compared to effector cells treated with CTRL siRNA, O3 siRNA-treated cells were significantly more inhibited by $100 \mu \mathrm{M} \mathrm{H}_{2} \mathrm{O}_{2}$ (Fig. 5F), thus confirming our prediction. We conclude that up-regulation of Orai 3 expression is necessary to change the redox sensitivity of CRAC-dependent $\mathrm{Ca}^{2+}$ influx in $\mathrm{T}$ cells.

To test whether effector $T_{H}$ cells develop additional protective mechanisms against oxidative stress that may explain the reduced sensitivity of the initial $\mathrm{H}_{2} \mathrm{O}_{2}$-induced $\mathrm{Ca}^{2+}$ influx, we determined the concentration of two major cellular antioxidants, glutathione and catalase. The concentrations of both reduced and total glutathione were increased in effector compared to naïve $\mathrm{T}_{\mathrm{H}}$ cells (fig. S5, A and B). Moreover, the activity of the $\mathrm{H}_{2} \mathrm{O}_{2}$ scavenger catalase was also significantly increased (fig. S4C). Both these results point toward a protection of redox-sensitive proteins containing cytosolic reactive cysteines, thereby reducing the initial effect of $\mathrm{H}_{2} \mathrm{O}_{2}$ on $\left[\mathrm{Ca}^{2+}\right]_{i}$.

\section{DISCUSSION}

Our data indicate that oxidation inhibits ORAI1 but not ORAI3 channel activity. This differential sensitivity can be largely explained by the presence of the extracellular cysteine $\mathrm{Cys}^{195}$ in ORAI1, which is absent in ORAI3. Although Cys ${ }^{195}$ is positioned close to the membrane, our data argue that it is reactive and amenable to oxidation. Mutation of Cys ${ }^{195}$ to

Table 1. Concentration of secreted IL-2 (ng/ml). Supernatants of naive and effector $T_{H}$ cells were collected and IL-2 concentrations were determined with an IL-2-specific ELISA. Values are means \pm SEM of three (effector) or four donors (naïve). The $P$ values were calculated with paired two-sided Student's $t$ test. N.S., not significant.

\begin{tabular}{|c|c|c|c|c|}
\hline & \multirow{2}{*}{ Naïve $T_{H}$ cells } & \multicolumn{3}{|c|}{ Effector $T_{H}$ cells } \\
\hline & & 24 hours & 48 hours & 72 hours \\
\hline $\begin{array}{l}0 \mu \mathrm{M} \mathrm{H}_{2} \mathrm{O}_{2} \\
100 \mu \mathrm{M} \mathrm{H}_{2} \mathrm{O}_{2} \\
\% \text { Inhibition by } 100 \mu \mathrm{M} \mathrm{H}_{2} \mathrm{O}_{2} \\
P \text { value }\end{array}$ & $\begin{array}{c}0.011 \pm 0.006 \\
0.004 \pm 0.0005 \\
\text { N.S. }\end{array}$ & $\begin{array}{c}6.09 \pm 1.2 \\
1.33 \pm 0.7 \\
78 \\
0.013\end{array}$ & $\begin{array}{c}11.8 \pm 0.9 \\
6.88 \pm 2.2 \\
42 \\
0.059\end{array}$ & $\begin{aligned} & 13.5 \pm 1.8 \\
& 10.83 \pm 1.9 \\
& 20 \\
& 0.45\end{aligned}$ \\
\hline
\end{tabular}


serine did not reduce current size or change the shape of the current-voltage relationship and thus does not lead to a major alteration of the selectivity filter $\left(\mathrm{E}^{106}, \mathrm{E}^{190}\right)[(38,39)$, see also $(40)]$. ORAI3 channels were not inhibited by $\mathrm{H}_{2} \mathrm{O}_{2}$, which was not only due to small current size because

A
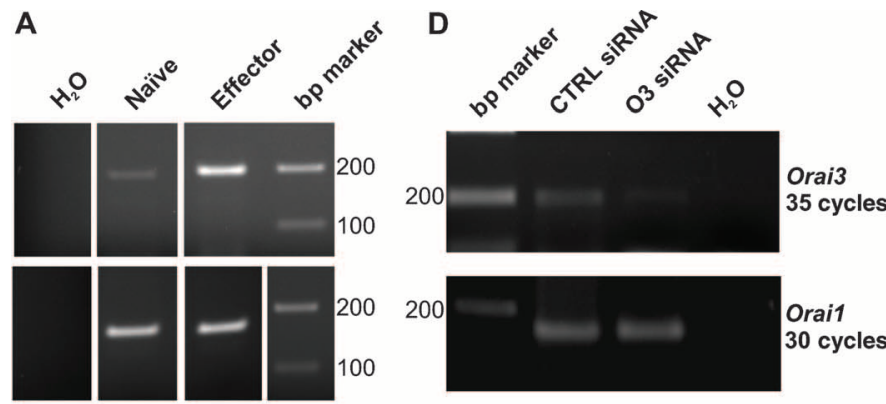

B

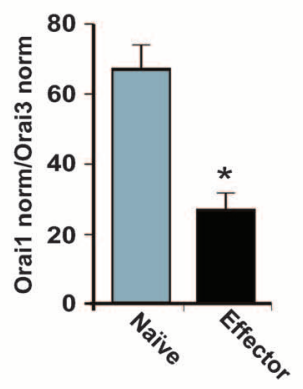

C

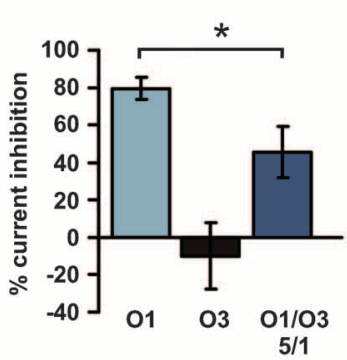

$\mathbf{F}$
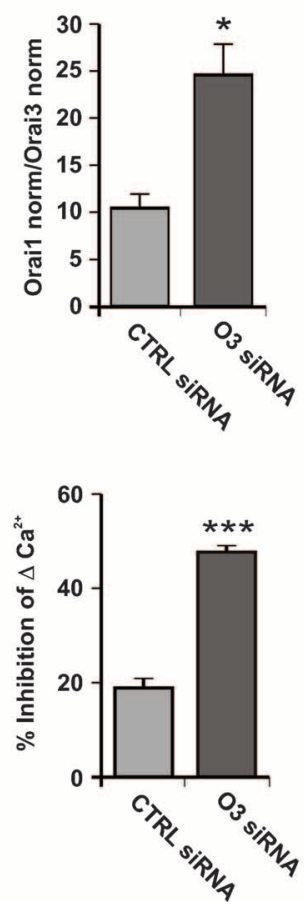

Fig. 5. ORAI3 reduces redox sensitivity of CRAC channels in effector $T_{H}$ cells. (A and B) qRT-PCR analyses of Orai1 and Orai3 expression in naïve and 72- to 96-hour effector $T_{H}$ cells. (B) Ratio of Orai1/Orai3 expression each normalized to RNA polymerase in naïve and effector $\mathrm{T}_{\mathrm{H}}$ cells. (C) Percent inhibition (CD $1 \mathrm{mM} \mathrm{H}_{2} \mathrm{O}_{2}$ /average unblocked CD) for HEKS1 cells expressing Orai1, Orai3, or Orai1 together with Orai3 at a ratio of $5: 1$. The total amount of DNA transfected was $1 \mu \mathrm{g}$ for each condition. ( $\mathrm{D}$ and $\mathrm{E}$ ) qRT-PCR analyses of Orai1 and Orai3 expression in naïve and 72- to 96-hour effector $T_{H}$ cells transfected with O3 siRNA or CTRL siRNA. (E) Ratio of Orai1/Orai3 expression each normalized to RNA polymerase in CTRL SiRNA- or O3 siRNA-transfected effector $\mathrm{T}_{\mathrm{H}}$ cells. (F) Percent inhibition $\left(\Delta\left[\mathrm{Ca}^{2+}\right]_{\mathrm{i}} 100 \mu \mathrm{M} \mathrm{H}_{2} \mathrm{O}_{2}\right.$ /average untreated $\left.\Delta\left[\mathrm{Ca}^{2+}\right]_{\mathrm{i}}\right)$ for effector $\mathrm{T}_{\mathrm{H}}$ cells transfected with CTRL siRNA or O3 SiRNA. For CTRL: $n=548\left(-\mathrm{H}_{2} \mathrm{O}_{2}\right), 675\left(+\mathrm{H}_{2} \mathrm{O}_{2}\right)$; for O3: $n=556\left(-\mathrm{H}_{2} \mathrm{O}_{2}\right), 486$ $\left(+\mathrm{H}_{2} \mathrm{O}_{2}\right) .{ }^{*} P<0.05,{ }^{* *} P<0.001$, unpaired Student's $t$ test. DNA ladder bands shown (A and D) are 200 and $100 \mathrm{bp}$. introduction of a cysteine in the homologous position (G170C) retained small currents that were now inhibited by $\mathrm{H}_{2} \mathrm{O}_{2}$. Current inhibition required preincubation with $\mathrm{H}_{2} \mathrm{O}_{2}$ and thus is not likely to act as an open pore blocker (fig. S1). Instead, oxidation of cysteines may lock the pore in the closed configuration, reduce single-channel conductance, the ability of ORAI1 to be effectively activated by STIM1, or the formation and/ or number of active ORAI1 channels.

We also found that primary $\mathrm{T}_{\mathrm{H}}$ cells from human blood donors were affected by changes in the redox state of the environment in multiple ways and that differentiation of naïve into effector $\mathrm{T}_{\mathrm{H}}$ cells changed the threshold of these modifications. Addition of $\mathrm{H}_{2} \mathrm{O}_{2}$ led to an immediate increase in $\left[\mathrm{Ca}^{2+}\right]_{\mathrm{i}}$ (initial effect) that was mediated through the activation of nonselective cation channels, possibly TRPM. $\mathrm{T}_{\mathrm{H}}$ cell differentiation shifted the activating $\mathrm{EC}_{50}$ values from $\sim 130$ to $\sim 740 \mu \mathrm{M}$. Because TRPM2 channels are activated by cytosolic second messengers such as cyclic adenosine diphosphate (ADP) ribose $(41,42)$ whose turnover rates are regulated by the oxidative stress-activated poly(ADPribose) polymerase (PARP-1) (43), up-regulation of cytosolic antioxidants (fig. S4) may provide a negative feedback mechanism for this pathway.

We cannot exclude a partial inhibition of Tg-induced increase in $\left[\mathrm{Ca}^{2+}\right]_{i}$ due to preceding membrane depolarization. However, the patch-clamp analyses of heterologously expressed ORAI1, Jurkat T cells, and effector $T$ cells demonstrated an inhibitory effect on the channels themselves. There was also an up-regulation of Orai3 in effector $\mathrm{T}_{\mathrm{H}}$ cells, and coexpression of Orail and Orai3 reduced redox sensitivity when expressed in HEKS1 cells (Fig. 5). Knockdown of Orai3 in human effector $\mathrm{T}_{\mathrm{H}}$ cells rendered $\mathrm{Ca}^{2+}$ influx again more redox sensitive and provides further support for direct redox regulation of the channels.

ORAI3 may work alone or in a heteromeric complex with ORAI1. Heteromeric ORAI1-ORAI3 channel assembly with a distinct selectivity profile has recently been described as a means not only to tune $\mathrm{Ca}^{2+}$ selectivity of store-operated $\mathrm{Ca}^{2+}$ entry (18), but also to generate channels activated independently of store depletion by arachidonic acid (44).

The up-regulation of Orai3 and other cytosolic antioxidants suggests that effector $\mathrm{T}_{\mathrm{H}}$ cells have developed adaptive mechanisms to both tune $\mathrm{Ca}^{2+}$ influx and scavenge increased intracellular ROS to respond to oxidative stress. Increased concentrations of ROS within injured or inflamed tissues can create gradients of ROS that, at low concentrations (nanomolar to low micromolar), enhance proliferation and cytokine production of effector $\mathrm{T}_{\mathrm{H}}$ cells (45-47) and thus may act as chemotactic signals (26). This enhancement could be due to an increase in $\left[\mathrm{Ca}^{2+}\right]_{\mathrm{i}}\left(\right.$ compare $\left[\mathrm{Ca}^{2+}\right]_{\mathrm{i}}$ and viability at $1 \mu \mathrm{M} \mathrm{H}_{2} \mathrm{O}_{2}$ against control for effector $\mathrm{T}_{\mathrm{H}}$ cells; red circles in Figs. 3D and 4D). In regions of $\mathrm{H}_{2} \mathrm{O}_{2}$ concentrations between $\sim 10$ and $\sim 300 \mu \mathrm{M}$, T cells will already undergo partial CRAC channel inhibition that will not yet affect their viability and cytokine production $(32,48)$, but may offset increases in $\left[\mathrm{Ca}^{2+}\right]_{\mathrm{i}}$ due to activation of TRPM channels. By up-regulation of ORAI3, effector $\mathrm{T}_{\mathrm{H}}$ cells would be able to tune their $\mathrm{Ca}^{2+}$ influx to continue proliferation and cytokine production in more oxidizing conditions. The Orai3 gene is the most recent addition to the Orai family and is present only in mammals (49), suggesting that ORAI3-dependent redox tuning might not take place in lower vertebrates. Local ROS concentrations might reach even higher levels through increased phagocytic activity, mitochondrial dysfunction, and massive activation of $\mathrm{T}$ cell receptor (TCR)-mediated signaling $(19,30)$. This could then ultimately activate TRPM channels $(36,37,42)$, release $\mathrm{Ca}^{2+}$ from intracellular stores $(50)$, increase protein phosphorylation levels (30), and eventually lead to apoptosis and tissue damage $(36,51,52)$.

Further investigations are necessary to elucidate the complex balance between physiological and pathological effects of oxidation and to test the role of dysregulation of Orai channel expression in disease. 


\section{MATERIALS AND METHODS}

\section{Chemicals}

All chemicals were purchased from Sigma unless indicated otherwise.

\section{Cell culture and isolation of primary $\mathrm{CD}^{+} \mathrm{T}_{\mathrm{H}}$ cells}

E6-1 Jurkat T cell line (American Type Culture Collection) and THP-1 monocyte cell line were grown in RPMI. HEKS1 cells were grown in Dulbecco's modified Eagle's medium (DMEM) supplemented with $10 \%$ fetal calf serum and penicillin-streptomycin at $37^{\circ} \mathrm{C}$ and $5 \% \mathrm{CO}_{2}$. Human $\mathrm{T}_{\mathrm{H}}$ cells were isolated from leukocyte reduction filters and collected by back-flushing the filter with $60 \mathrm{ml}$ of Hanks' balanced salt solution (HBSS; PAA, 15-009). Peripheral blood lymphocytes (PBLs) were isolated by a density gradient centrifugation at $450 \mathrm{~g}$ for $30 \mathrm{~min}$ at room temperature (Ficoll-Paque PLUS, Amersham Biosciences, 17144002) in 50-ml Leucosep tubes (Greiner, 227290). The PBL layer was washed in HBSS. Remaining red blood cells were removed by the addition of $1 \mathrm{ml}$ of lysis buffer $\left[155 \mathrm{mM} \mathrm{NH}_{4} \mathrm{Cl}, 10 \mathrm{mM} \mathrm{KHCO}_{3}, 0.1\right.$ mM EDTA (pH 7.3)] for $1 \mathrm{~min}$. After lysis, cells were washed with HBSS [200g, $10 \mathrm{~min}$ at room temperature (RT)]. For further purification, PBLs were resuspended in phosphate-buffered saline (PBS) and $0.5 \%$ bovine serum albumin, and $\mathrm{CD} 4^{+} \mathrm{T}$ cells were negatively isolated with the $\mathrm{CD}^{+}$Negative Isolation Kit (to avoid prestimulation) from Invitrogen (113.17D), following the manufacturer's instruction (32).

\section{Constructs and transfection}

hOrail 1 and hOrai 3 constructs were subcloned into pCAGGS-IRES-GFP. Mutagenesis was performed by means of Quickchange (Stratagene) with an Orail-SmaI fragment in pBluescript as a template. The mutated SmaI fragment was excised and cloned into mEGFP-Orail pMAX vector (Lonza) with a deleted Smal vector site. This construct served as a template to reclone the full-length mutants into pCAGGS-IRES-GFP. For creating triple mutants, mutant SmaI fragments were used as a template. All constructs were confirmed by sequencing. For transfection, $1 \mu \mathrm{g}$ of DNA was electroporated into HEKS1 cells with the Nucleofector II electroporator (Lonza) and Nucleofector kit (Lonza). Cells were transfected according to the manufacturer's instructions and seeded 24 hours before measurements.

\section{Small interfering RNA transfection}

Orai3 small interfering RNAs (siRNAs) Hs_TMEM142C_2 [sense: 5' r(OMeC-OMeA-CCAGUGGCUACCUCC)d(CUU)d(OMeA-OMeTOMeT) 3'; antisense: 3' r(OMeG-OMeT-GGUCACCGAUGGAGGGAA)d(U) 5' (\#SI04174191)] and Hs_TMEM142C_5 [sense: 5'r (OMeT-OMeCCUUAGCCCUUGAAAU)d(ACA)d(OMeA-OMeT-OMeT) $3^{\prime}$; antisense:

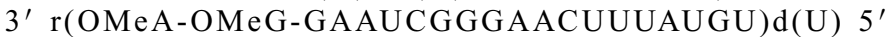
(\#SI04348876)] and CTRL siRNA (\#1022076) from Qiagen were chemically modified by the addition of two deoxy or methoxy groups (to increase stability) (53). $\mathrm{CD}^{+} \mathrm{T}_{\mathrm{H}}$ cells were stimulated with self-made beads coated with antibodies against CD3 and CD28 (32). Cells $\left(5 \times 10^{6}\right)$ were nucleofected with $8.0 \mu \mathrm{l}$ of siRNA or CTRL siRNA $(20 \mu \mathrm{M})$ using Nucleofector technology (Lonza) according to the manufacturer's instructions. For down-regulation of Orai3, a 1:1 mixture of both Orai3 siRNAs was used.

\section{Fluorescence-based $\mathrm{Ca}^{2+}$ imaging}

External solution (buffer A) contained $155 \mathrm{mM} \mathrm{NaCl}, 4.5 \mathrm{mM} \mathrm{KCl}, 2 \mathrm{mM}$ $\mathrm{MgCl}_{2}, 10 \mathrm{mM}$ D-glucose, $5 \mathrm{mM}$ Hepes (pH 7.4 with $\mathrm{NaOH}$ ), and $\mathrm{CaCl}_{2}$ at $0.5 \mathrm{mM}$ (for HEKS1 cells) or $1 \mathrm{mM}$ (for T cells). Cells were loaded with $1 \mu \mathrm{M}$ Fura 2-AM. Images were analyzed with TILL Vision software.
$\left[\mathrm{Ca}^{2+}\right]_{\mathrm{i}}$ was estimated from the relation $\left[\mathrm{Ca}^{2+}\right]_{\mathrm{I}}=K^{*}\left(R-R_{\min }\right) /\left(R_{\max }-R\right)$, where the values of $K^{*}, R_{\min }$, and $R_{\max }$ were determined from an in situ calibration of Fura 2 in $\mathrm{T}_{\mathrm{H}}$ and HEK293 cells as described in $(54,55)$. To exclude nonspecific effects of $\mathrm{H}_{2} \mathrm{O}_{2}$ on $\mathrm{Ca}^{2+}$ measurements, we analyzed the redox properties of Fura 2 (56).

\section{Electrophysiology: T cells}

Patch-clamp experiments were performed in the whole-cell configuration with fire-polished patch pipettes ( 3 to 5 megohm). Pipette and cell capacitance were electronically compensated before each voltage ramp with an EPC-9 patch-clamp amplifier controlled by Pulse 8.4 or Patchmaster software (HEKA). Membrane currents were sampled at $3 \mathrm{kHz}$ and filtered at $1 \mathrm{kHz}$. Whole-cell currents were elicited by $200-\mathrm{ms}$ voltage ramps from -100 to $+100 \mathrm{mV}$ from a holding potential of $0 \mathrm{mV}$. To measure leak currents, 20 voltage ramps were applied within the first $5 \mathrm{~s}$ after establishment of the whole-cell configuration, followed by ramps applied every second. All voltages were corrected for a liquid junction potential of $-12 \mathrm{mV}$. For leak current correction, the ramp current before CRAC activation was subtracted. The solutions used for measurements of $I_{\mathrm{CRAC}}$ were as follows: pipette: $140 \mathrm{mM}$ cesium aspartate, $10 \mathrm{mM} \mathrm{NaCl}, 5 \mathrm{mM}$ $\mathrm{MgCl}_{2}, 10 \mathrm{mM}$ EGTA, and $10 \mathrm{mM}$ Hepes (pH 7.2 with $\mathrm{CsOH}$ ); bath solution: $155 \mathrm{mM} \mathrm{NaCl}, 4.5 \mathrm{mM} \mathrm{KCl}, 10 \mathrm{mM} \mathrm{CaCl}, 2 \mathrm{mM} \mathrm{MgCl}_{2}$, $10 \mathrm{mM}$ D-glucose, and $5 \mathrm{mM}$ Hepes ( $\mathrm{pH} 7.4$ with $\mathrm{NaOH}$ ). $\mathrm{H}_{2} \mathrm{O}_{2}$-induced currents were measured as in (37).

\section{HEK cells}

Whole-cell currents were elicited by 50 -ms ramps from -150 to $+150 \mathrm{mV}$ at $0.5 \mathrm{~Hz}$ from a holding potential of $0 \mathrm{mV}$. For leak current correction, the ramp current before ORAI activation was subtracted. Cells with an initial inward current greater than $-10 \mathrm{pA} / \mathrm{pF}(-130 \mathrm{mV})$ and significant outliers $(P<0.01$, Grubb's test) were excluded. Voltages were corrected for a liquid junction potential of $-10 \mathrm{mV}$. The internal solution contained $120 \mathrm{mM}$ cesium glutamate, $20 \mathrm{mM}$ cesium.BAPTA [1,2-bis(2-aminophenoxy)ethane$N, N, N^{\prime}, N^{\prime}$-tetraacetic acid], $3 \mathrm{mM} \mathrm{MgCl} 2,0.05 \mathrm{mM} \mathrm{IP3}$, and $10 \mathrm{mM}$ Hepes (pH 7.2 with $\mathrm{CsOH}$ ). The external solution contained $120 \mathrm{mM} \mathrm{NaCl}$, $10 \mathrm{mM} \mathrm{CaCl}_{2}, 2 \mathrm{mM} \mathrm{MgCl}, 10 \mathrm{mM}$ TEA-HCl (tetraethylammonium chloride), $10 \mathrm{mM}$ glucose, and $10 \mathrm{mM}$ Hepes (pH 7.2 with $\mathrm{NaOH}$ ). Inward and outward currents were analyzed at -80 and $+80 \mathrm{mV}$ ramp potential for both $\mathrm{T}$ cells and HEK cells.

\section{DTNB-2Bio labeling assay}

The DTNB-2Bio labeling assay was performed as previously described with modifications (57). HEK cells transfected with EGFP-hOrai1, EGFP-hOrai1_C195S, EGFP-hOrai1_C126S/C143S/C195S, or EGFPOrai3 $\left(\sim 7 \times 10^{6}\right)$ were washed with PBS. Membranes were permeabilized with $0.001 \%$ digitonin for $5 \mathrm{~min}$. Cells were collected and incubated in Hepes-buffered saline (HBS) solution with or without $1 \mathrm{mM} \mathrm{H}_{2} \mathrm{O}_{2}$ for $15 \mathrm{~min}$ followed by $50 \mu \mathrm{M}$ DTNB-2Bio for $40 \mathrm{~min}$ at RT. Cells were washed with HBS and lysed in radioimmunoprecipitation assay (RIPA) buffer ( $\mathrm{pH} 8.0$ ) containing $150 \mathrm{mM} \mathrm{NaCl}, 1 \%$ Nonidet P-40, $0.5 \%$ sodium deoxycholate, $0.1 \%$ SDS, $50 \mathrm{mM}$ tris, $1 \mathrm{mM}$ phenylmethylsulfonyl fluoride, aprotinin $(5 \mu \mathrm{g} / \mathrm{ml})$ and leupeptin $(1 \mu \mathrm{g} / \mathrm{ml})$. Cell lysates were incubated with NeutrAvidin-Plus beads (Thermo-Scientific) overnight at $4^{\circ} \mathrm{C}$ with constant shaking. Beads were rinsed five times with RIPA buffer by centrifugation at $15,000 \mathrm{rpm}$ for $1 \mathrm{~min}$. Proteins were eluted in RIPA buffer containing $50 \mathrm{mM}$ dithiothreitol (DTT) for $60 \mathrm{~min}$ and denatured in SDS sample buffer containing $50 \mathrm{mM}$ DTT for $30 \mathrm{~min}$ at room temperature. Proteins were analyzed by $7.5 \%$ SDS-polyacrylamide gel electrophoresis (SDS-PAGE), transferred to membrane, and detected with an antibody against GFP (Clontech). 


\section{Cell viability and proliferation}

Measurements were carried out in 96-well cell culture plates (BD). Each data point was measured in triplicate. Naïve $T_{H}$ cells $(50,000)$ were seeded in a total volume of $200 \mu \mathrm{l}$ of AIM V medium. For effector $\mathrm{T}_{\mathrm{H}}$ cell measurements, these were then activated with antibody (against CD3 and $\mathrm{CD} 28$ )-coated beads (Invitrogen) and incubated at $37^{\circ} \mathrm{C}, 5 \% \mathrm{CO}_{2}$, and $95 \%$ humidity. Living cells were detected with the CellTiter-Blue assay (Promega) (32).

\section{Measurements of IL-2 secretion}

After proliferation was measured, 96-well plates were centrifuged ( $150 \mathrm{~g}$ $7 \mathrm{~min}, \mathrm{RT}$ ) and supernatants were collected and frozen for later use. Different dilutions of the supernatants and of an IL-2 standard were then analyzed in duplicates with an ELISA assay (DuoSet; DY202, R\&D Systems) according to the manufacturer's instructions. Supernatants from four (naïve) and three (effector) $\mathrm{T}_{\mathrm{H}}$ cell donors were analyzed.

\section{qRT-PCR}

Total RNA was isolated from naïve and effector $\mathrm{T}_{\mathrm{H}}$ cells [(2.5 to 8.0) $\times$ $10^{6}$ each, stimulated with antibody (against CD3 and CD28)-coated beads for 72 hours] from five donors. Isolated total RNA $(1.5 \mu \mathrm{l})$ or total RNA $(1 \mu \mathrm{g})$ was used for reverse transcription. Complementary DNA (cDNA; $0.5 \mu \mathrm{l}$ ) and $300 \mathrm{nM}$ primer were used in a QuantiTect SYBR green kit (Qiagen). PCR conditions were as follows: $15 \mathrm{~min}$ at $94^{\circ} \mathrm{C}$; 45 cycles, $30 \mathrm{~s}$ at $94^{\circ} \mathrm{C} ; 45 \mathrm{~s}$ at $58^{\circ} \mathrm{C}$; and $30 \mathrm{~s}$ at $72^{\circ} \mathrm{C}$ with a final cycle $\left(60 \mathrm{~s}\right.$ at $95^{\circ} \mathrm{C}, 30 \mathrm{~s}$ at $55^{\circ} \mathrm{C}$, and $30 \mathrm{~s}$ at $95^{\circ} \mathrm{C}$ ) using the MX3000 cycler (Stratagene). Primers were designed as described in http://frodo.wi.mit.edu/. Expression of Orail and Orai3 was normalized to the expression of the housekeeping gene RNA polymerase II (NM_000937). Relative expression was calculated according to the $\Delta \mathrm{CT}$ method $\left(2^{-\Delta \mathrm{CT}}\right) \mathrm{CT}$ values were determined by the MX3000 software. The reliability of the housekeeping gene was also confirmed by a second house keeping gene, TATA box binding protein (NM_003194). To calculate primer efficiencies, raw fluorescence data from MX3000 measurements were analyzed by fitting the early exponential phase of the reaction and correcting the CT value accordingly (IgorPro macro). Primer sequences for Orail were $5^{\prime}$ atgagcctcaacgagcact3' and 5'gtgggtagtcgtggtcag $3^{\prime}$ [159 base pairs (bp)] and for Orai3 were $5^{\prime}$ 'gtaccgggagttcgtgca3' and 5'ggtactcgtggtcactct3' (193 bp). All primer pairs span an intron-exon boundary to avoid amplification of genomic DNA. Amplification products were confirmed by DNA sequencing (MWG).

\section{Determination of glutathione and catalase activity}

One million naïve or effector $\mathrm{T}_{\mathrm{H}}$ cells (per sample) were lysed by consecutive freezing and thawing, centrifuged for $10 \mathrm{~min}$ at 14,000 rpm, resuspended in PBS buffer, and kept on ice. Total glutathione was determined with the fluorescent dye monochlorobimane (MCB, $100 \mu \mathrm{M}$ ). The reaction was catalyzed by glutathione $S$-transferase (GST; $1 \mathrm{U} / \mathrm{ml}$ ). All measurements were performed with a microplate reader (GeniosPro, Tecan). Reduced glutathione was measured with the fluorescent dye $o$-phthalaldehyde (OPA, $5 \mathrm{mg} / \mathrm{ml}$ ). Cell lysates were deproteinized with $6 \mathrm{M}$ perchloric acid for $5 \mathrm{~min}$ and centrifuged for $5 \mathrm{~min}$ at 14,000 rpm. $\mathrm{pH}$ was restored (7-11) with $3 \mathrm{M} \mathrm{NaOH}$. Supernatants were used for further measurements. Catalase activity was determined with a spectrophotometer (Ultrospec 2100) using absorption of $\mathrm{H}_{2} \mathrm{O}_{2}$ at $240 \mathrm{~nm}$ according to Beers and Sizer (58). One million cells were lysed in $120 \mu \mathrm{l}$ of PBS buffer containing $0.1 \%$ Triton X-100. Lysates were centrifuged for $10 \mathrm{~min}$ at $14,000 \mathrm{rpm}$ and supernatants were measured with quartz cuvettes (1QS). The supernatant $(100 \mu \mathrm{l})$ was mixed with $2.9 \mathrm{ml}$ of PBS buffer containing $10 \mathrm{mM} \mathrm{H}_{2} \mathrm{O}_{2}$. Absorbance at $240 \mathrm{~nm}\left(A_{240}\right)$ was recorded every $30 \mathrm{~s}$ for $10 \mathrm{~min}$. The final catalase concentration per cell was calculated according to a standard curve determined with different concentrations (units per milliliter) of recombinant catalase as reference.

\section{Data analysis and statistics}

Data were analyzed with TILL Vision (TILL Photonics), Fitmaster 2.35 (HEKA), Igor Pro (Wavemetrics), and Microsoft Excel (Microsoft). Data are means \pm SEM unless otherwise indicated. Asterisks indicate significance: $* P<0.05,{ }^{*} P<0.01, * * * P<0.001$ (unpaired, two-sided Student's $t$ test). Primary human $\mathrm{T}_{\mathrm{H}}$ cells were isolated from at least two different healthy donors. For each condition, at least three experiments were performed. For calculation of $\mathrm{IC}_{50}$ values, data were fitted with Hill's equations (least-squares method).

\section{SUPPLEMENTARY MATERIALS}

www.sciencesignaling.org/cgi/content/full/3/115/ra24/DC1

Fig. S1. Activated CRAC channels are not inhibited by $\mathrm{H}_{2} \mathrm{O}_{2}$.

Fig. S2. $\mathrm{H}_{2} \mathrm{O}_{2}$ effect on ORAI2 and current/voltage relationships of ORAI1WT, ORAI1TM, ORAI1C195S and ORAI3WT

Fig. S3. $\mathrm{H}_{2} \mathrm{O}_{2}$ activates nonselective ion channels.

Fig. S4. Orai3 siRNA down-regulates ORAI3 protein.

Fig. S5. Relative amounts and activity of cellular antioxidants in naïve and effector $T_{H}$ cells.

\section{REFERENCES AND NOTES}

1. M. J. Berridge, P. Lipp, M. D. Bootman, The versatility and universality of calcium signalling. Nat. Rev. Mol. Cell Biol. 1, 11-21 (2000).

2. J. W. Putney Jr., A model for receptor-regulated calcium entry. Cell Calcium 7, 1-12 (1986).

3. M. Hoth, R. Penner, Depletion of intracellular calcium stores activates a calcium current in mast cells. Nature 355, 353-356 (1992).

4. A. B. Parekh, J. W. Putney Jr., Store-operated calcium channels. Physiol. Rev. $\mathbf{8 5}$ 757-810 (2005).

5. S. L. Zhang, Y. Yu, J. Roos, J. A. Kozak, T. J. Deerinck, M. H. Ellisman, K. A. Stauderman, M. D. Cahalan, STIM1 is a $\mathrm{Ca}^{2+}$ sensor that activates CRAC channels and migrates from the $\mathrm{Ca}^{2+}$ store to the plasma membrane. Nature 437, 902-905 (2005)

6. J. Liou, M. L. Kim, W. D. Heo, J. T. Jones, J. W. Myers, J. E. Ferrell Jr., T. Meyer, STIM is a $\mathrm{Ca}^{2+}$ sensor essential for $\mathrm{Ca}^{2+}$-store-depletion-triggered $\mathrm{Ca}^{2+}$ influx. Curr. Biol. 15, 1235-1241 (2005)

7. S. Feske, Y. Gwack, M. Prakriya, S. Srikanth, S. H. Puppel, B. Tanasa, P. G. Hogan, R. S. Lewis, M. Daly, A. Rao, A mutation in Orai1 causes immune deficiency by abrogating CRAC channel function. Nature 441, 179-185 (2006).

8. M. Vig, C. Peinelt, A. Beck, D. L. Koomoa, D. Rabah, M. Koblan-Huberson, S. Kraft, H. Turner, A. Fleig, R. Penner, J. P. Kinet, CRACM1 is a plasma membrane protein essential for store-operated $\mathrm{Ca}^{2+}$ entry. Science 312, 1220-1223 (2006).

9. S. L. Zhang, A. V. Yeromin, X. H. Zhang, Y. Yu, O. Safrina, A. Penna, J. Roos K. A. Stauderman, M. D. Cahalan, Genome-wide RNAi screen of $\mathrm{Ca}^{2+}$ influx identifies genes that regulate $\mathrm{Ca}^{2+}$ release-activated $\mathrm{Ca}^{2+}$ channel activity. Proc. Natl. Acad. Sci. U.S A. 103, 9357-9362 (2006).

10. C. Y. Park, P. J. Hoover, F. M. Mullins, P. Bachhawat, E. D. Covington, S. Raunser, T. Walz, K. C. Garcia, R. E. Dolmetsch, R. S. Lewis, STIM1 clusters and activates CRAC channels via direct binding of a cytosolic domain to Orai1. Cell 136, 876-890 (2009).

11. M. Muik, M. Fahrner, I. Derler, R. Schindl, J. Bergsmann, I. Frischauf, K. Groschner, C. Romanin, A cytosolic homomerization and a modulatory domain within STIM1 C terminus determine coupling to ORAl1 channels. J. Biol. Chem. 284, 8421-8426 (2009).

12. S. Feske, Calcium signalling in lymphocyte activation and disease. Nat. Rev. Immunol. 7, 690-702 (2007).

13. R. S. Lewis, The molecular choreography of a store-operated calcium channel. Nature 446, 284-287 (2007)

14. S. A. Gross, U. Wissenbach, S. E. Philipp, M. Freichel, A. Cavalie, V. Flockerzi, Murine ORAI2 splice variants form functional $\mathrm{Ca}^{2+}$ release-activated $\mathrm{Ca}^{2+}$ (CRAC) channels. J. Biol. Chem. 282, 19375-19384 (2007).

15. Y. Gwack, S. Srikanth, S. Feske, F. Cruz-Guilloty, M. Oh-hora, D. S. Neems, P. G. Hogan, A. Rao, Biochemical and functional characterization of Orai proteins. J. Biol. Chem. 282, 16232-16243 (2007).

16. I. Frischauf, R. Schindl, I. Derler, J. Bergsmann, M. Fahrner, C. Romanin, The STIM/Orai coupling machinery. Channels (Austin) 2, 261-268 (2008). 
17. A. Lis, C. Peinelt, A. Beck, S. Parvez, M. Monteilh-Zoller, A. Fleig, R. Penner, CRACM1, CRACM2, and CRACM3 are store-operated $\mathrm{Ca}^{2+}$ channels with distinct functional properties. Curr. Biol. 17, 794-800 (2007).

18. R. Schindl, I. Frischauf, J. Bergsmann, M. Muik, I. Derler, B. Lackner, K. Groschner, C. Romanin, Plasticity in $\mathrm{Ca}^{2+}$ selectivity of Orai1/Orai3 heteromeric channel. Proc. Natl. Acad. Sci. U.S A. 106, 19623-19628 (2009).

19. W. Dröge, Free radicals in the physiological control of cell function. Physiol. Rev. 82 , 47-95 (2002).

20. S. G. Rhee, Cell signaling: $\mathrm{H}_{2} \mathrm{O}_{2}$, a necessary evil for cell signaling. Science $\mathbf{3 1 2}$, 1882-1883 (2006).

21. J. D. Lambeth, NOX enzymes and the biology of reactive oxygen. Nat. Rev. Immunol. 4, 181-189 (2004).

22. A. A. Starkov, The role of mitochondria in reactive oxygen species metabolism and signaling. Ann. N.Y. Acad. Sci. 1147, 37-52 (2008).

23. I. Fridovich, Fundamental aspects of reactive oxygen species, or what's the matter with oxygen? Ann. N.Y. Acad. Sci. 893, 13-18 (1999).

24. C. F. Nathan, R. K. Root, Hydrogen peroxide release from mouse peritoneal macrophages: Dependence on sequential activation and triggering. J. Exp. Med. 146 , 1648-1662 (1977)

25. S. Mueller, Sensitive and nonenzymatic measurement of hydrogen peroxide in biological systems. Free Radic. Biol. Med. 29, 410-415 (2000).

26. P. Niethammer, C. Grabher, A. T. Look, T. J. Mitchison, A tissue-scale gradient of hydrogen peroxide mediates rapid wound detection in zebrafish. Nature 459, 996999 (2009)

27. X. Liu, J. L. Zweier, A real-time electrochemical technique for measurement of cellular hydrogen peroxide generation and consumption: Evaluation in human polymorphonuclear leukocytes. Free Radic. Biol. Med. 31, 894-901 (2001).

28. S. M. Davidson, M. R. Duchen, Calcium microdomains and oxidative stress. Cell Calcium 40, 561-574 (2006).

29. C. Amatore, S. Arbault, C. Bouton, K. Coffi, J. C. Drapier, H. Ghandour, Y. Tong, Monitoring in real time with a microelectrode the release of reactive oxygen and nitrogen species by a single macrophage stimulated by its membrane mechanical depolarization. Chembiochem 7, 653-661 (2006).

30. M. Reth, Hydrogen peroxide as second messenger in lymphocyte activation. Nat. Immunol. 3, 1129-1134 (2002).

31. J. Soboloff, M. A. Spassova, X. D. Tang, T. Hewavitharana, W. Xu, D. L. Gill, Orai and STIM reconstitute store-operated calcium channel function. J. Biol. Chem. 281, 20661-20665 (2006).

32. E. C. Schwarz, C. Kummerow, A. S. Wenning, K. Wagner, A. Sappok, K. Waggershauser, D. Griesemer, B. Strauss, M. J. Wolfs, A. Quintana, M. Hoth, Calcium dependence of T cell proliferation following focal stimulation. Eur. J. Immunol. 37, 2723-2733 (2007)

33. K. Hill, C. D. Benham, S. McNulty, A. D. Randall, Flufenamic acid is a pH-dependent antagonist of TRPM2 channels. Neuropharmacology 47, 450-460 (2004).

34. M. D. Cahalan, K. G. Chandy, The functional network of ion channels in T lymphocytes Immunol. Rev. 231, 59-87 (2009).

35. Y. Sano, K. Inamura, A. Miyake, S. Mochizuki, H. Yokoi, H. Matsushime, K. Furuichi, Immunocyte $\mathrm{Ca}^{2+}$ influx system mediated by LTRPC2. Science 293, 1327-1330 (2001).

36. M. Aarts, K. lihara, W. L. Wei, Z. G. Xiong, M. Arundine, W. Cerwinski, J. F. MacDonald M. Tymianski, A key role for TRPM7 channels in anoxic neuronal death. Cell115, 863-877 (2003).

37. Y. Hara, M. Wakamori, M. Ishii, E. Maeno, M. Nishida, T. Yoshida, H. Yamada, S. Shimizu, E. Mori, J. Kudoh, N. Shimizu, H. Kurose, Y. Okada, K. Imoto, Y. Mori, LTRPC2 Ca ${ }^{2+}$ permeable channel activated by changes in redox status confers susceptibility to cell death. Mol. Cell 9, 163-173 (2002).

38. A. V. Yeromin, S. L. Zhang, W. Jiang, Y. Yu, O. Safrina, M. D. Cahalan, Molecular identification of the CRAC channel by altered ion selectivity in a mutant of Orai. Nature 443, 226-229 (2006).

39. M. Vig, A. Beck, J. M. Billingsley, A. Lis, S. Parvez, C. Peinelt, D. L. Koomoa, J. Soboloff, D. L. Gill, A. Fleig, J. P. Kinet, R. Penner, CRACM1 multimers form the ion-selective pore of the CRAC channel. Curr. Biol. 16, 2073-2079 (2006)

40. B. A. McNally, M. Yamashita, A. Engh, M. Prakriya, Structural determinants of ion permeation in CRAC channels. Proc. Natl. Acad. Sci. U.S A. 106, 22516-22521 (2009).

41. M. Kolisek, A. Beck, A. Fleig, R. Penner, Cyclic ADP-ribose and hydrogen peroxide synergize with ADP-ribose in the activation of TRPM2 channels. Mol. Cell 18, 61-69 (2005)

42. B. A. Miller, The role of TRP channels in oxidative stress-induced cell death. J. Membr. Biol. 209, 31-41 (2006)
43. B. Buelow, Y. Song, A. M. Scharenberg, The Poly(ADP-ribose) polymerase PARP-1 is required for oxidative stress-induced TRPM2 activation in lymphocytes. J. Biol. Chem. 283, 24571-24583 (2008).

44. O. Mignen, J. L. Thompson, T. J. Shuttleworth, The molecular architecture of the arachidonate-regulated $\mathrm{Ca}^{2+}$-selective ARC channel is a pentameric assembly of Orai1 and Orai3 subunits. J. Physiol. 587, 4181-4197 (2009).

45. S. Roth, W. Dröge, Regulation of T-cell activation and T-cell growth factor (TCGF) production by hydrogen peroxide. Cell. Immunol. 108, 417-424 (1987).

46. S. Tatla, V. Woodhead, J. C. Foreman, B. M. Chain, The role of reactive oxygen species in triggering proliferation and IL-2 secretion in T cells. Free Radic. Biol. Med. 26, 14-24 (1999).

47. S. P. Hehner, R. Breitkreutz, G. Shubinsky, H. Unsoeld, K. Schulze-Osthoff, M. L. Schmitz, W. Dröge, Enhancement of $T$ cell receptor signaling by a mild oxidative shift in the intracellular thiol pool. J. Immunol. 165, 4319-4328 (2000).

48. C. Zitt, B. Strauss, E. C. Schwarz, N. Spaeth, G. Rast, A. Hatzelmann, M. Hoth, Potent inhibition of $\mathrm{Ca}^{2+}$ release-activated $\mathrm{Ca}^{2+}$ channels and T-lymphocyte activation by the pyrazole derivative BTP2. J. Biol. Chem. 279, 12427-12437 (2004).

49. X. Cai, Molecular evolution and structural analysis of the $\mathrm{Ca}^{2+}$ release-activated $\mathrm{Ca}^{2+}$ channel subunit, Orai. J. Mol. Biol. 368, 1284-1291 (2007).

50. C. Hidalgo, P. Donoso, Crosstalk between calcium and redox signaling: From molecular mechanisms to health implications. Antioxid. Redox. Signal. 10, 1275-1312 (2008)

51. P. Tripathi, D. Hildeman, Sensitization of T cells to apoptosis-A role for ROS? Apoptosis 9, 515-523 (2004).

52. Y. Imai, K. Kuba, G. G. Neely, R. Yaghubian-Malhami, T. Perkmann, G. van Loo, M. Ermolaeva, R. Veldhuizen, Y. H. C. Leung, H. Wang, H. Liu, Y. Sun, M. Pasparakis, M. Kopf, C. Mech, S. Bavari, J. S. M. Peiris, A. S. Slutsky, S. Akira, M. Hultqvist, R. Holmdahl, J. Nicholls, C. Jiang, C. J. Binder, J. M. Penninger, Identification of oxidative stress and Toll-like receptor 4 signaling as a key pathway of acute lung injury. Cell 133, 235-249 (2008)

53. A. Mantei, S. Rutz, M. Janke, D. Kirchhoff, U. Jung, V. Patzel, U. Vogel, T. Rudel, I. Andreou, M. Weber, A. Scheffold, siRNA stabilization prolongs gene knockdown in primary T lymphocytes. Eur. J. Immunol. 38, 2616-2625 (2008).

54. A. Quintana, E. C. Schwarz, C. Schwindling, P. Lipp, L. Kaestner, M. Hoth, Sustained activity of calcium release-activated calcium channels requires translocation of mitochondria to the plasma membrane. J. Biol. Chem. 281, 40302-40309 (2006).

55. G. Grynkiewicz, M. Poenie, R. Y. Tsien, A new generation of $\mathrm{Ca}^{2+}$ indicators with greatly improved fluorescence properties. J. Biol. Chem. 260, 3440-3450 (1985)

56. R. Gulaboski, C. M. Pereira, M. N. Cordeiro, A. F. Silva, M. Hoth, I. Bogeski, Redox properties of the calcium chelator Fura-2 in mimetic biomembranes. Cell Calcium 43, 615-621 (2008).

57. T. Yoshida, R. Inoue, T. Morii, N. Takahashi, S. Yamamoto, Y. Hara, M. Tominaga, S. Shimizu, Y. Sato, Y. Mori, Nitric oxide activates TRP channels by cysteine S-nitrosylation. Nat. Chem. Biol. 2, 596-607 (2006).

58. R. F. Beers Jr., I. W. Sizer, A spectrophotometric method for measuring the breakdown of hydrogen peroxide by catalase. J. Biol. Chem. 195, 133-140 (1952).

59. Acknowledgments: Research carried out for this study with human material has been approved by the local ethics committee. We are grateful to $\mathrm{S}$. Kiyonaka for providing the DTNB2-Biotin and J. Soboloff for providing HEKS1 cells. We thank B. Strauß, A. Ludes, and $A$. Armbrüster for technical assistance. Funding: This project was funded by the Deutsche Forschungsgemeinschaft (DFG; SFB 530, project A3, and the Graduate Programs GK1326 and GK845, to M.H. and B.A.N.) and competitive research grants from the Saarland University (HOMFOR to M.H., I.B., C.P., and B.A.N.). C.P. acknowledges funding by the DFG (PE 1478/5-1). Author contributions: I.B. performed all imaging experiments. D.A.,C.K., B.A.N., C.P., and I.B. performed patch-clamp experiments. D.A. and B.A.N. cloned all constructs. E.C.S. contributed qRT-PCR data. D.K., N.T., and Y.M. contributed DTNB2-Bio data. I.B. and R.K. performed glutathione and catalase measurements. M.B., I.B., and D.A. conducted proliferation and IL-2 measurements. D.G. and C.P. provided initial technical support and reagents. I.B., Y.M., M.H., and B.A.N. designed experiments, analyzed the data, and wrote the paper. Competing interests: The authors have no conflicting financial interests.

Submitted 2 October 2009

Accepted 3 March 2010

Final Publication 30 March 2010

10.1126/scisignal.2000672

Citation: I. Bogeski, C. Kummerow, D. Al-Ansary, E. C. Schwarz, R. Koehler, D. Kozai, N. Takahashi, C. Peinelt, D. Griesemer, M. Bozem, Y. Mori, M. Hoth, B. A. Niemeyer, Differential redox regulation of ORAI ion channels: A mechanism to tune cellular calcium signaling. Sci. Signal. 3, ra24 (2010). 


\section{Supplementary Materials for \\ Differential Redox Regulation of ORAI Ion Channels: A Mechanism to Tune Cellular Calcium Signaling}

Ivan Bogeski, * Carsten Kummerow, Dalia Al-Ansary, Eva C. Schwarz, Richard Koehler, Daisuke Kozai, Nobuaki Takahashi, Christine Peinelt, Desiree Griesemer, Monika

Bozem, Yasuo Mori, Markus Hoth, Barbara A. Niemeyer*

*To whom correspondence should be addressed. E-mail: ivan.bogeski@uks.eu (I.B.);

barbara.niemeyer@uks.eu (B.A.N.)

Published 30 March 2010, Sci. Signal. 3, ra24 (2010)

DOI: $10.1126 /$ scisignal.2000672

\section{The PDF file includes:}

Fig. S1. Activated CRAC channels are not inhibited by $\mathrm{H}_{2} \mathrm{O}_{2}$.

Fig. S2. $\mathrm{H}_{2} \mathrm{O}_{2}$ effect on ORAI2 and current/voltage relationships of ORAI1WT, ORAI1TM, ORAI1C195S and ORAI3WT.

Fig. S3. $\mathrm{H}_{2} \mathrm{O}_{2}$ activates nonselective ion channels.

Fig. S4. Orai3 siRNA down-regulates ORAI3 protein.

Fig. S5. Relative amounts and activity of cellular antioxidants in naïve and effector $\mathrm{T}_{\mathrm{H}}$ cells. 
A

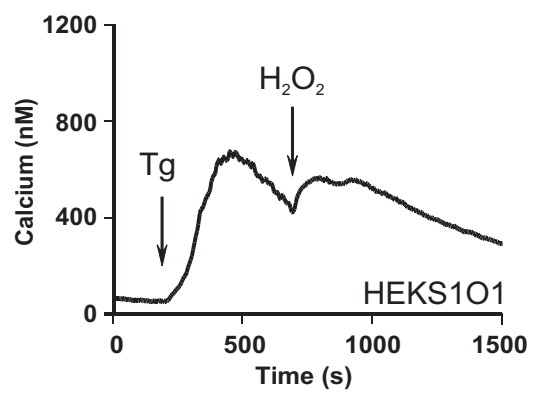

D

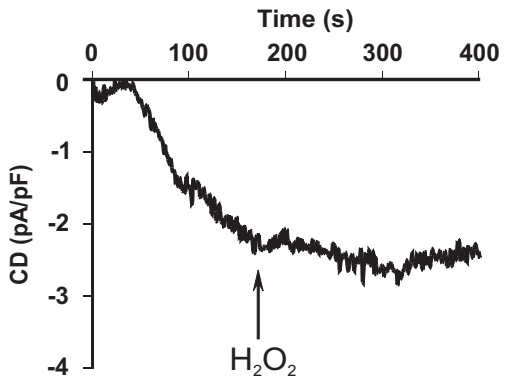

B

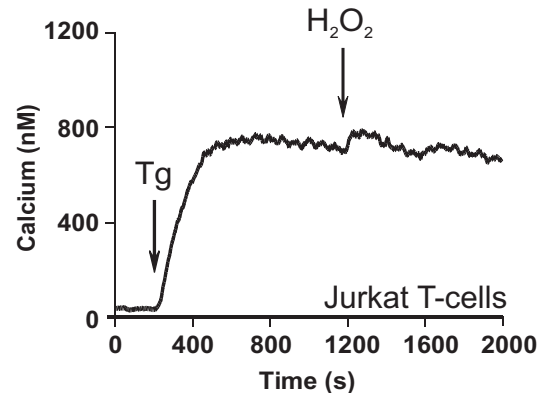

E

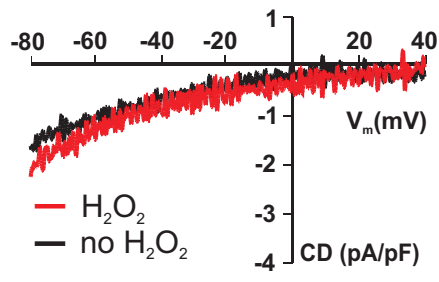

C

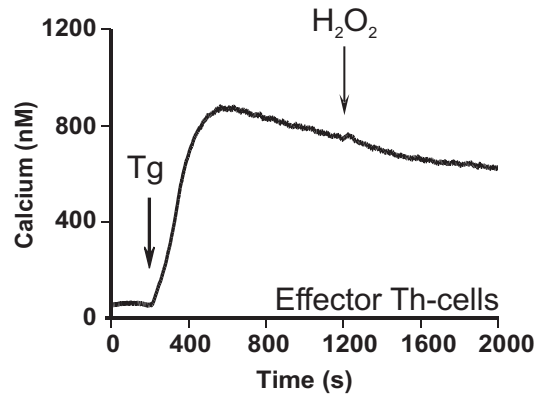

$\mathbf{F}$

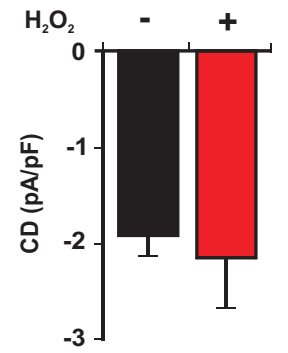

Figure S1: Activated CRAC channels are not inhibited by $\mathrm{H}_{2} \mathrm{O}_{2}$

$\left[\mathrm{Ca}^{2+}\right]_{i}$ measurements in (A) HEKS1O1 cells, $n=72$, (B) Jurkat T cells, $n=244$, and (C) effector Th cells, $n=102$. $500 \mu \mathrm{M}$ of $\mathrm{H}_{2} \mathrm{O}_{2}$ (arrow) was added following CRAC channel activation by $1 \mu \mathrm{M} \mathrm{Tg}$. (D) $\mathrm{I}_{\text {CRAC }}$ in Jurkat T cells was induced by store depletion with $10 \mathrm{mM}$ EGTA and analyzed at $-80 \mathrm{mV}$ (representative experiment is shown). $500 \mu \mathrm{M} \mathrm{H}_{2} \mathrm{O}_{2}$ was added at $\sim 3 \mathrm{~min}$ (arrow). Current-voltage relationship (E) and average CD $\pm \mathrm{SD}$ $(F)$ at $300 \mathrm{~s}$ of untreated cells (black, $n=5$ ) or of cells treated for $\sim 120$ seconds with $500 \mu \mathrm{M} \mathrm{H}_{2} \mathrm{O}_{2}$ (red, $n=6$ ) following $I_{C R A C}$ development. 
A

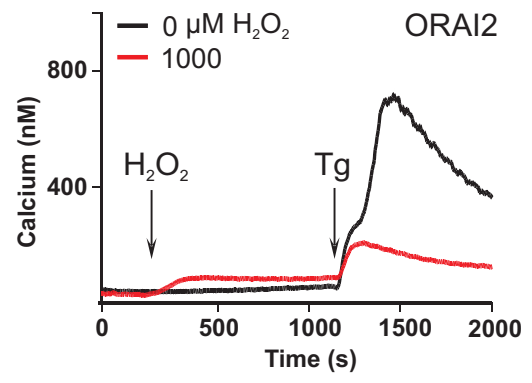

B

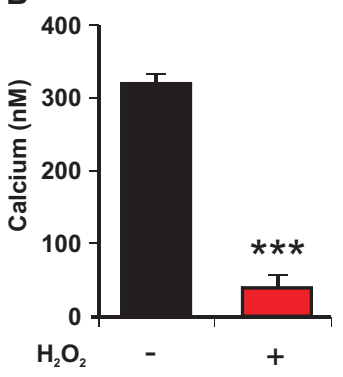

C

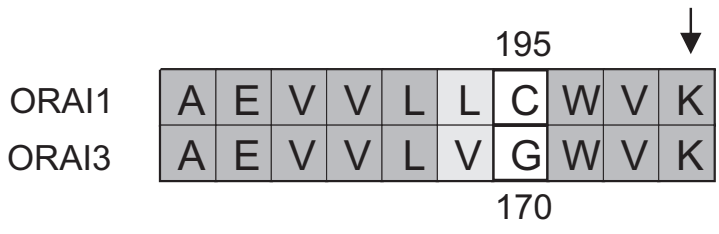

D

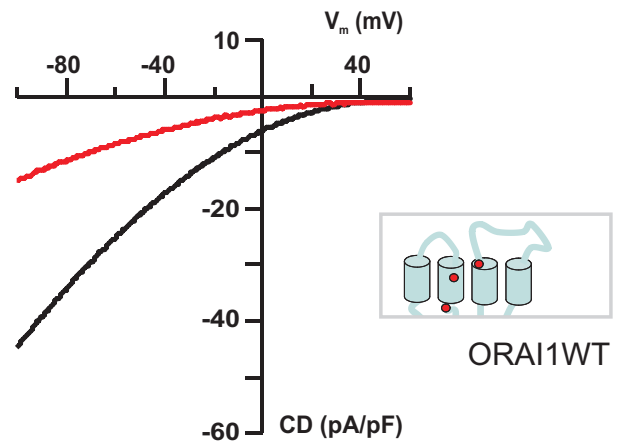

$\mathbf{F}$

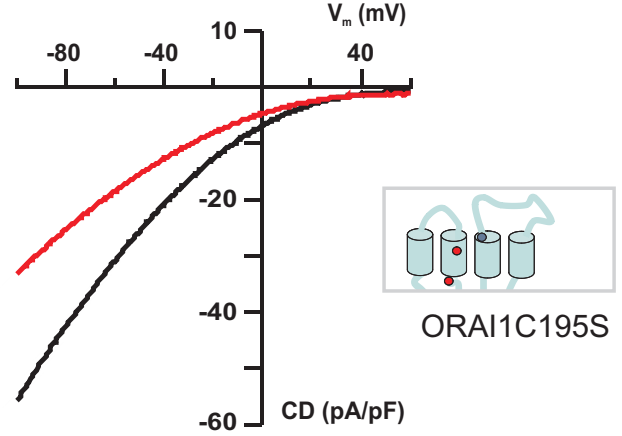

E

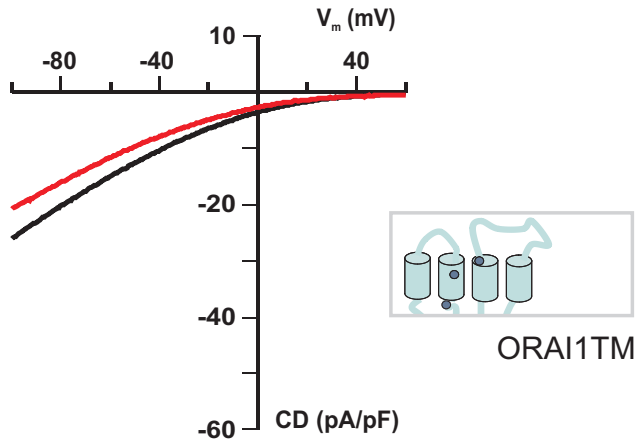

G

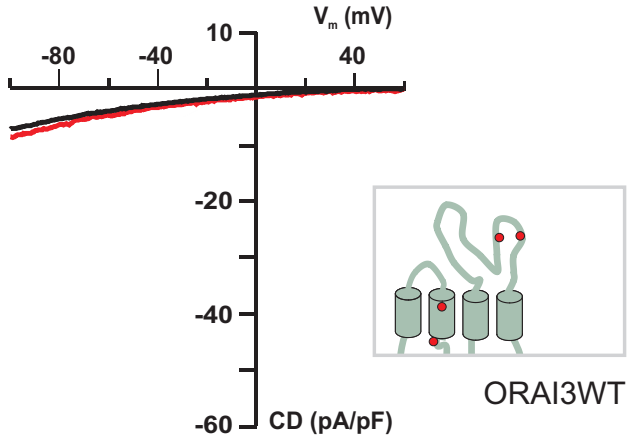

Figure S2: $\mathrm{H}_{2} \mathrm{O}_{2}$ effect on ORAl2 and current/voltage relationships of ORAl1WT, ORAI1TM, ORAI1C195S and ORAI3WT

$\left[\mathrm{Ca}^{2+}\right]_{\mathrm{i}}$ in $\mathrm{HEKS} 1 \mathrm{O} 2$ cells before and after addition of $\mathrm{Tg}$, and without $\mathrm{H}_{2} \mathrm{O}_{2}$ (black trace, $\mathrm{n}=82)$ red: $1 \mathrm{mM} \mathrm{H}_{2} \mathrm{O}_{2}(\mathrm{n}=47)$. (B)Tg-induced $\Delta\left[\mathrm{Ca}^{2+}\right]_{i}$ between $1200-2000$ seconds without (black) and after treatment with $1 \mathrm{mM} \mathrm{H}_{2} \mathrm{O}_{2}$ (C) Alignment of the distal transmembrane region 3 between ORAl 1 and ORAl3. Arrow indicates a negatively charged residue in the vicinity of the reactive C195 (D-G) Average current voltage relationships for ORAI1WT, ORAI1TM, ORAI1C195S and ORAI3WT untreated (black) and treated with $1 \mathrm{mM} \mathrm{H}_{2} \mathrm{O}_{2}$ (red). 
A

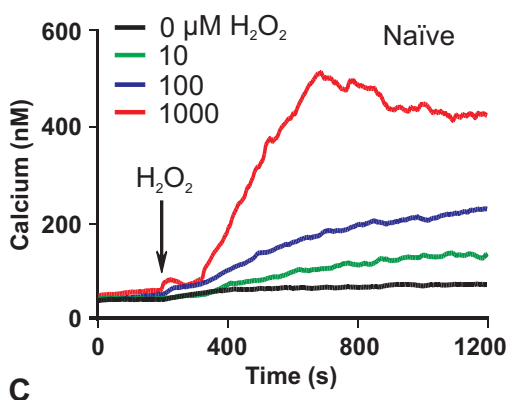

C

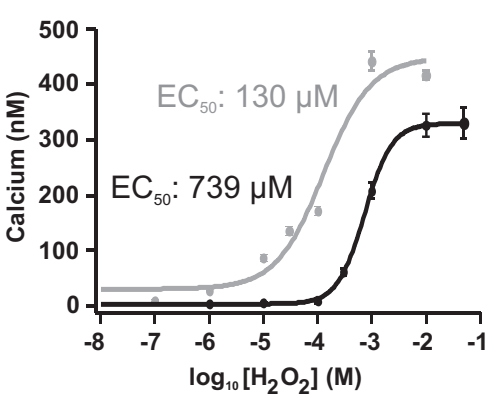

E

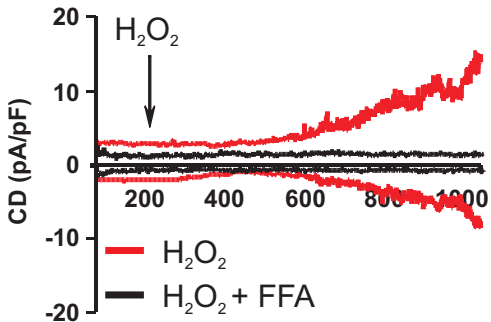

Time (s)

G

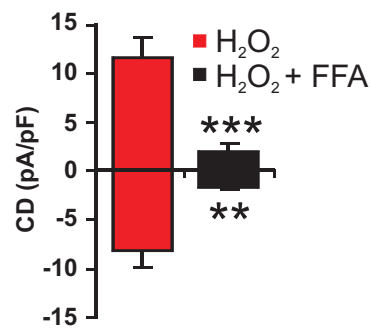

B
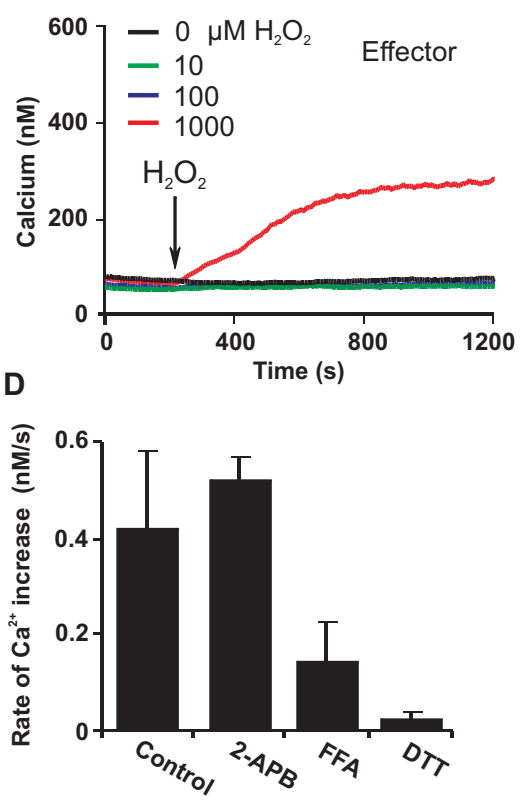

$\mathbf{F}$

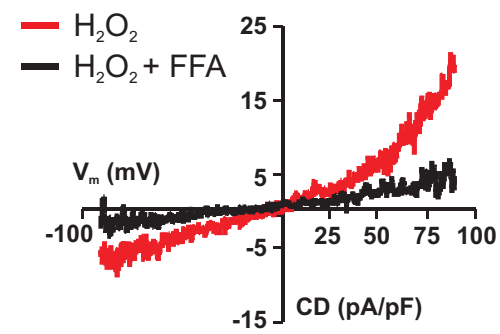

H

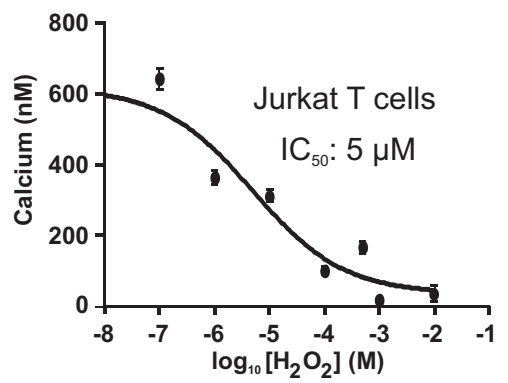

Figure S3: $\mathrm{H}_{2} \mathrm{O}_{2}$ activates nonselective ion channels.

$(A, B)\left[\mathrm{Ca}^{2+}\right]_{i}$ in naïve $(A)$ and effector Th cells $(B) . \mathrm{H}_{2} \mathrm{O}_{2}$ was added as indicated. $n \geq 340(A)$ and $\geq 239(B)$ for all conditions. (C) Dose dependence of $\left[\mathrm{Ca}^{2+}\right]_{i}$ on $\left[\mathrm{H}_{2} \mathrm{O}_{2}\right]\left(\left[\mathrm{Ca}^{2+}\right]_{i} @ 1190 \mathrm{sec}-\left[\mathrm{Ca}^{2+}\right]_{i} @ 190 \mathrm{sec}\right) \pm \mathrm{SEM}$. Naïve Th cells (grey), effector Th cells (black). (D) The effect of $100 \mu \mathrm{M}$ 2-APB, $100 \mu \mathrm{M}$ FFA and $10 \mathrm{mM}$ DTT on $\mathrm{H}_{2} \mathrm{O}_{2}(500 \mu \mathrm{M})$ induced increase in $\left[\mathrm{Ca}^{2+}\right]_{i}$. Slope calculations (nM against time) were used to determine the rate of increase in $\left[\mathrm{Ca}^{2+}\right]_{1}$ induced by $\mathrm{H}_{2} \mathrm{O}_{2}$. Data are mean $\pm \mathrm{SD}(n=3)$. $(E) \mathrm{H}_{2} \mathrm{O}_{2}$-induced current measurements in Jurkat T cells. Currents were analyzed at $-80 \mathrm{mV}$ and at $+80 \mathrm{mV}$ ramp potential and plotted against time: red $\left(1 \mathrm{mM} \mathrm{H}_{2} \mathrm{O}_{2}\right)$, black $\left(1 \mathrm{mM} \mathrm{H}_{2} \mathrm{O}_{2}+100 \mu \mathrm{M} \mathrm{FFA}\right)$. ( $\left.\mathrm{F}\right)$ Current-voltage relationship of cells treated with $1 \mathrm{mM} \mathrm{H}_{2} \mathrm{O}_{2}$ (red, $\mathrm{n}=5$ ) and cells treated with $1 \mathrm{mM} \mathrm{H}_{2} \mathrm{O}_{2}$ and $100 \mu \mathrm{M} \mathrm{FFA}$ (black, $\mathrm{n}=4$ ). (G) Average CD \pm SD after $800 \mathrm{~s}$. (H) Dependence of $\left[\mathrm{Ca}^{2+}\right]_{i}$ on $\left[\mathrm{H}_{2} \mathrm{O}_{2}\right]\left(\left[\mathrm{Ca}^{2+}\right]_{i} @ 2000 \mathrm{~s}-\left[\mathrm{Ca}^{2+}\right]_{i} @ 1200 \mathrm{~s}\right) \pm \mathrm{SEM}$ in Jurkat T cells. 


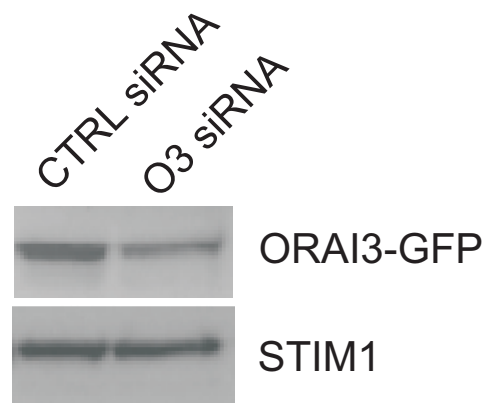

Figure S4. Orai3 siRNA downregulates ORAI3 protein.

HEKS1 cells were transiently transfected with $1 \mu \mathrm{g}$ ORAI3GFP and either $1.6 \mu \mathrm{M}$ CTRL siRNA or with $1.6 \mu \mathrm{M}$ O3 siRNA. Cells were lysed after $48 \mathrm{~h}$. Detection using anti-GFP or anti-STIM1 antibodies. 
A

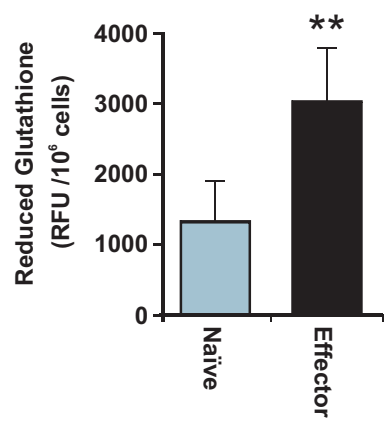

B

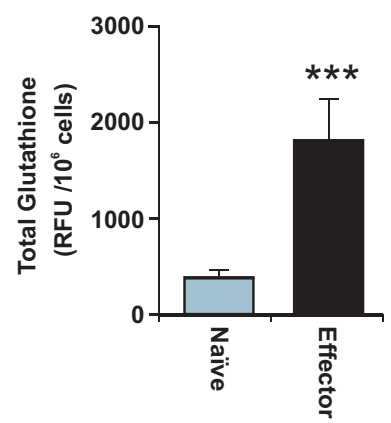

C

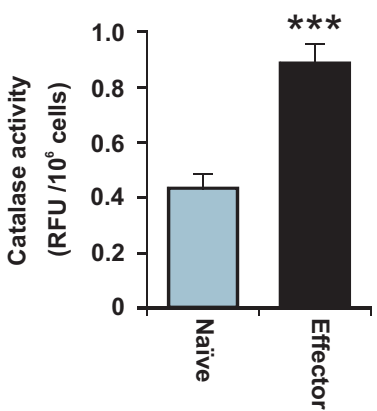

Figure S5: Relative amounts and activity of cellular antioxidants in naïve and effector Th cells.

Reduced (A) and total (B) glutathione concentration in naïve (light blue, $n=5$ ) and effector (black, $n=5$ ) Th cells. Data are mean $\pm S D$. (C) Catalase activity in naïve (light blue, $n=7$ ) and effector (black, $n=6$ ) Th cells. Data are mean $\pm S D$. 